Prepared in cooperation with the

PUERTO RICO INDUSTRIAL DEVELOPMENT COMPANY

\title{
Characterization of Stormwater Discharges from Selected Industrial Parks in Puerto Rico, 1995-96
}




\section{Cover Photo}

Discharge point of outfalls 1 and 2 (below bridge) of the Sabanetas Industrial Park, Ponce, Puerto Rico. This photo was taken looking northeast from the right bank, downstream of the bridge by Carlos R. Santos in July 1998. 


\title{
Characterization of Stormwater Discharges from Selected Industrial Parks in Puerto Rico, 1995-96
}

\author{
By José M. Rodríguez
}

U.S. GEOLOGICAL SURVEY

Water-Resources Investigations Report 98-4045

Prepared in cooperation with the

PUERTO RICO INDUSTRIAL DEVELOPMENT COMPANY

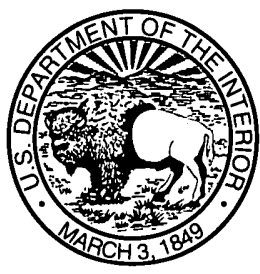




\title{
U.S. DEPARTMENT OF THE INTERIOR BRUCE BABBITT, Secretary
}

\author{
U.S. GEOLOGICAL SURVEY
}

Thomas J. Casadevall, Acting Director

For additional information write to:

District Chief

U.S. Geological Survey

GSA Center, Suite 400-15

651 Federal Drive

Guaynabo, Puerto Rico 00965-5703
Copies of this report can be purchased from:

U.S. Geological Survey

Branch of Information Services

Box 25286

Denver, C0 80225-0286 


\section{CONTENTS}

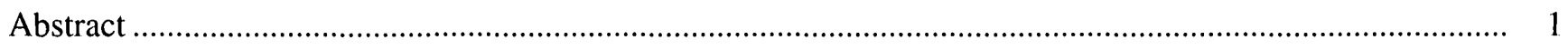

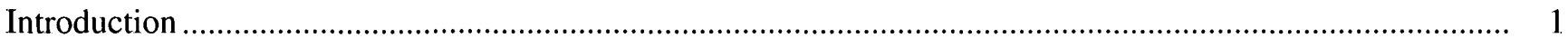

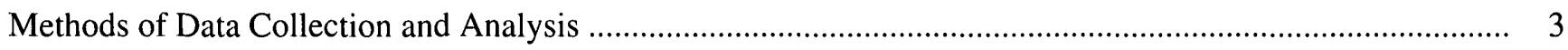

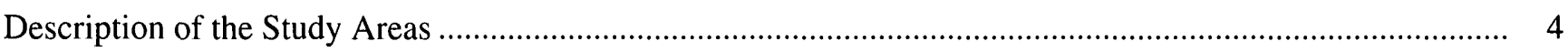

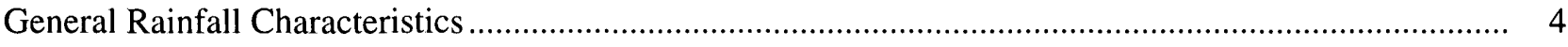

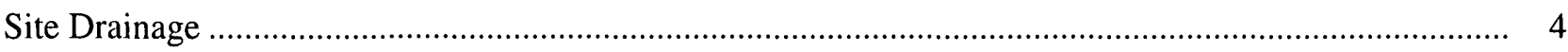

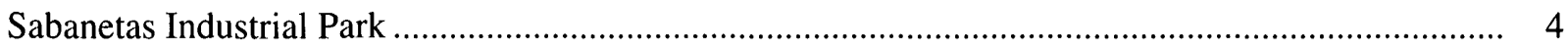

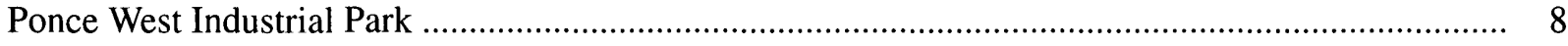

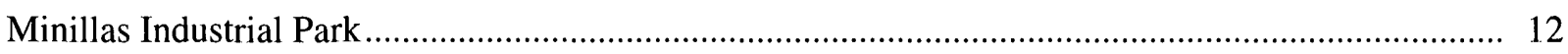

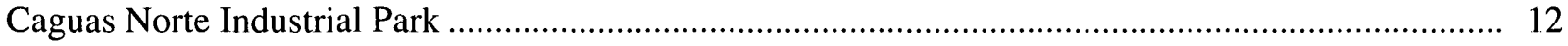

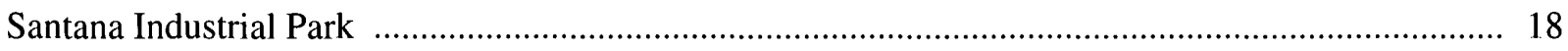

Zeno Gandía Industrial Park .............................................................................................. 20

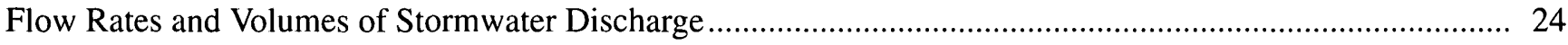

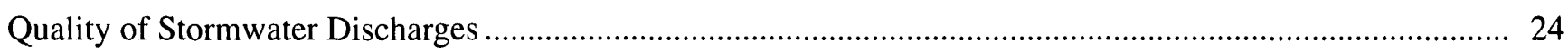

Constituent Concentrations at Individual Sites ........................................................................... 31

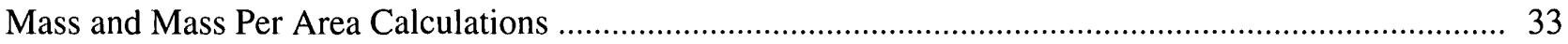

Relation of Storm Characteristics to Stormwater Quality ...................................................................... 33

Relation of Industrial Activities to Stormwater Quality ......................................................................... 43

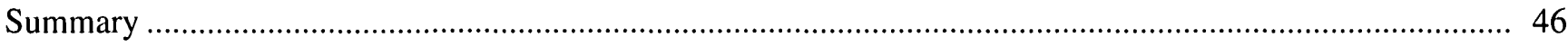

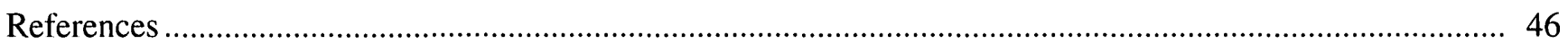

\section{ILLUSTRATIONS}

1.-17. Maps showing

1. General location of study areas and mean annual rainfall distribution in Puerto Rico..................... 2

2. Location of the Sabanetas Industrial Park (SIP), Ponce, Puerto Rico .............................................. 5

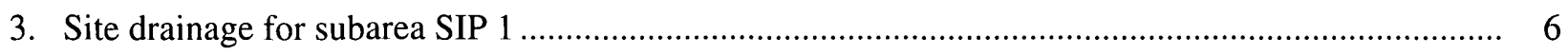

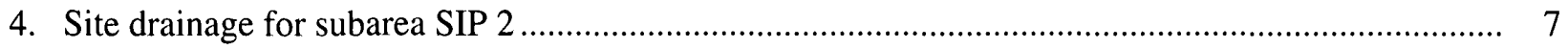

5. Location of the Ponce West Industrial Park (PWIP), Ponce, Puerto Rico ........................................ 9

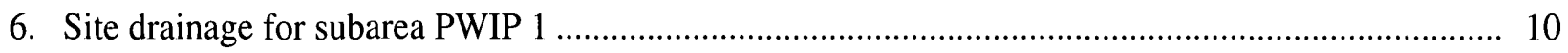

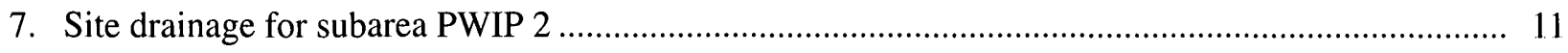

8. Location of the Minillas Industrial Park (MIP), Bayamón, Puerto Rico ......................................... 13

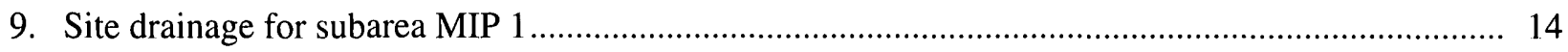


10. Site drainage for subarea MIP 2

11. Location of the Caguas Norte Industrial Park (CNIP), Caguas, Puerto Rico

12. Site drainage for subarea CNIP

13. Location of the Santana Industrial Park (SAIP), Arecibo, Puerto Rico

14. Site drainage for subarea SAIP.

15. Location of the Zeno Gandía Industrial Park (ZGIP), Arecibo, Puerto Rico

16. Site drainage for subarea ZGIP 1

17. Site drainage for subarea ZGIP 2

\section{8.-21. Graphs showing}

18. Constituent concentration of stormwater discharges from industrial parks and urban subareas in Puerto Rico.

19. Relation of constituent concentration in grab samples with the rain intensity of the storm events

20. Relation of constituent concentration in composite samples to volume of runoff at each studied industrial subarea

21. Relation of constituent concentration in grab samples with the dry period preceding the sampled event.

\section{TABLES}

1. Estimated area covered by impervious surfaces and total area drained by each outfall in the studied subareas of the selected industrial parks .....

2. Characteristics of the studied storm events at selected industrial parks in Puerto Rico.....

3. Physical and chemical characteristics of stormwater discharges from selected industrial parks in Puerto Rico

4. Trace metals in stormwater discharges from selected industrial parks in Puerto Rico......

5. Stormwater benchmark concentrations determined by the U.S. Environmental Protection Agency....

6. Summary of subareas where constituent concentrations exceeded benchmark values

7. Mass of selected water-quality constituents and properties of stormwater discharges from selected industrial parks in Puerto Rico

8. Mass per area of selected water-quality constituents and properties of stormwater discharges from selected industrial parks in Puerto Rico...

9. Industrial activities at selected industrial parks in Puerto Rico 


\section{CONVERSION FACTORS, ABBREVIATED WATER-QUALITY UNITS, AND ACRONYMS}

\begin{tabular}{rll}
\hline Multiply & \multicolumn{1}{c}{ By } & To obtain \\
\hline millimeter $(\mathrm{mm})$ & 0.03937 & inch (in) \\
meter $(\mathrm{m})$ & 3.281 & foot $(\mathrm{ft})$ \\
square meter $\left(\mathrm{m}^{2}\right)$ & 10.76 & square foot $\left(\mathrm{ft}^{2}\right)$ \\
cubic meter $\left(\mathrm{m}^{3}\right)$ & 35.31 & cubic foot $\left(\mathrm{ft}^{3}\right)$ \\
liter per second $(\mathrm{L} / \mathrm{s})$ & 0.03531 & cubic foot per second $\left(\mathrm{ft}^{3} / \mathrm{s}\right)$ \\
\hline
\end{tabular}

\section{Abbreviated water-quality units used in this report:}

microsiemens per centimeter $(\mu \mathrm{S} / \mathrm{cm})$

milligram per liter $(\mathrm{mg} / \mathrm{L})$

milligram per square meter $\left(\mathrm{mg} / \mathrm{m}^{2}\right)$

grams $(\mathrm{g})$

\section{Acronyms}

$\begin{array}{ll}\text { BMRK } & \text { Benchmark concentration } \\ \text { BOD } & \text { Biochemical oxygen demand } \\ \text { CNIP } & \text { Caguas Norte Industrial Park } \\ \text { COD } & \text { Chemical oxygen demand } \\ \text { MIP } & \text { Minillas Industrial Park } \\ \text { NPDES } & \text { National Pollutant Discharge Elimination System } \\ \text { PRIDCO } & \text { Puerto Rico Industrial Development Company } \\ \text { PWIP } & \text { Ponce West Industrial Park } \\ \text { SAIP } & \text { Santana Industrial Park } \\ \text { SIC } & \text { Standard Industrial Classification } \\ \text { SIP } & \text { Sabanetas Industrial Park } \\ \text { SW } & \text { Stormwater } \\ \text { TKN } & \text { Ammonia plus organic nitrogen } \\ \text { TOC } & \text { Total organic carbon } \\ \text { TP } & \text { Total phosphorus } \\ \text { TSS } & \text { Total suspended solids } \\ \text { URBS } & \text { Urban sewered } \\ \text { URBU } & \text { Urban unsewered } \\ \text { USEPA } & \text { U.S. Environmental Protection Agency } \\ \text { USGS } & \text { U.S. Geological Survey } \\ \text { ZGIP } & \text { Zeno Gandía Industrial Park }\end{array}$




\title{
Characterization of Stormwater Discharges from Selected Industrial Parks in Puerto Rico, 1995-96
}

\author{
By José M. Rodríguez
}

\section{Abstract}

Stormwater discharges from six selected industrial parks in Puerto Rico were investigated from 1995 to 1996 by measuring the flow rate and collecting samples at 10 outfalls. The drainage areas for each outfall were delineated and calculated. The flow rate was used to calculate the volume of the discharges. The collected samples were analyzed to determine the quality of the discharges. Constituent mass and mass per area were estimated for each drainage area.

The average concentrations of oil and grease and total phosphorus from samples collected at most of the studied subareas were less than the U.S. Environmental Protection Agency stormwater benchmark concentrations. Average concentrations of chemical oxygen demand and total suspended solids exceeded the benchmark concentrations in eight of the sampled drainage areas. High concentrations of constituents associated to pollution by organic material found in several of the studied subareas suggest the presence of waste discharges in the storm sewer.

\section{INTRODUCTION}

Studies conducted on a nationwide scale have demonstrated that runoff from urban and industrial areas is a significant source of surface-water pollution (U.S. Environmental Protection Agency, 1983). Data obtained during these studies indicates that urban and industrial runoff contains some pollutants in quantities comparable to, and in some cases greater than, effluents from wastewater secondary-treatment plants.

To control the quality of the stormwater discharges, the Federal Water Pollution Control Act, as amended in 1987 [section 402(p)], required the U.S. Environmental Protection Agency (USEPA) to establish regulations under the National Pollutant Discharge Elimination System (NPDES) for stormwater discharges associated with industrial activity. The regulations require the owners or operators of facilities discharging stormwater associated with industrial activity to comply with certain criteria.

From April 1995 to April 1996, the U.S. Geological Survey (USGS) in cooperation with the Puerto Rico Industrial Development Company (PRIDCO) conducted a study to characterize the stormwater discharges at selected industrial parks in Puerto Rico (fig. 1). The six selected industrial parks are among more than 250 industrial areas located throughout Puerto Rico in which PRIDCO is the owner of most of the industrial lots. The selected parks are principal industrial areas due to their areal extension and their location in major cities of the island.

This study investigated the characteristics of the stormwater discharges from industrial areas in Puerto Rico. The information collected during these studies will improve the understanding of the stormwater discharges and indicate areas that may need improvement relating to stormwater management practices. 


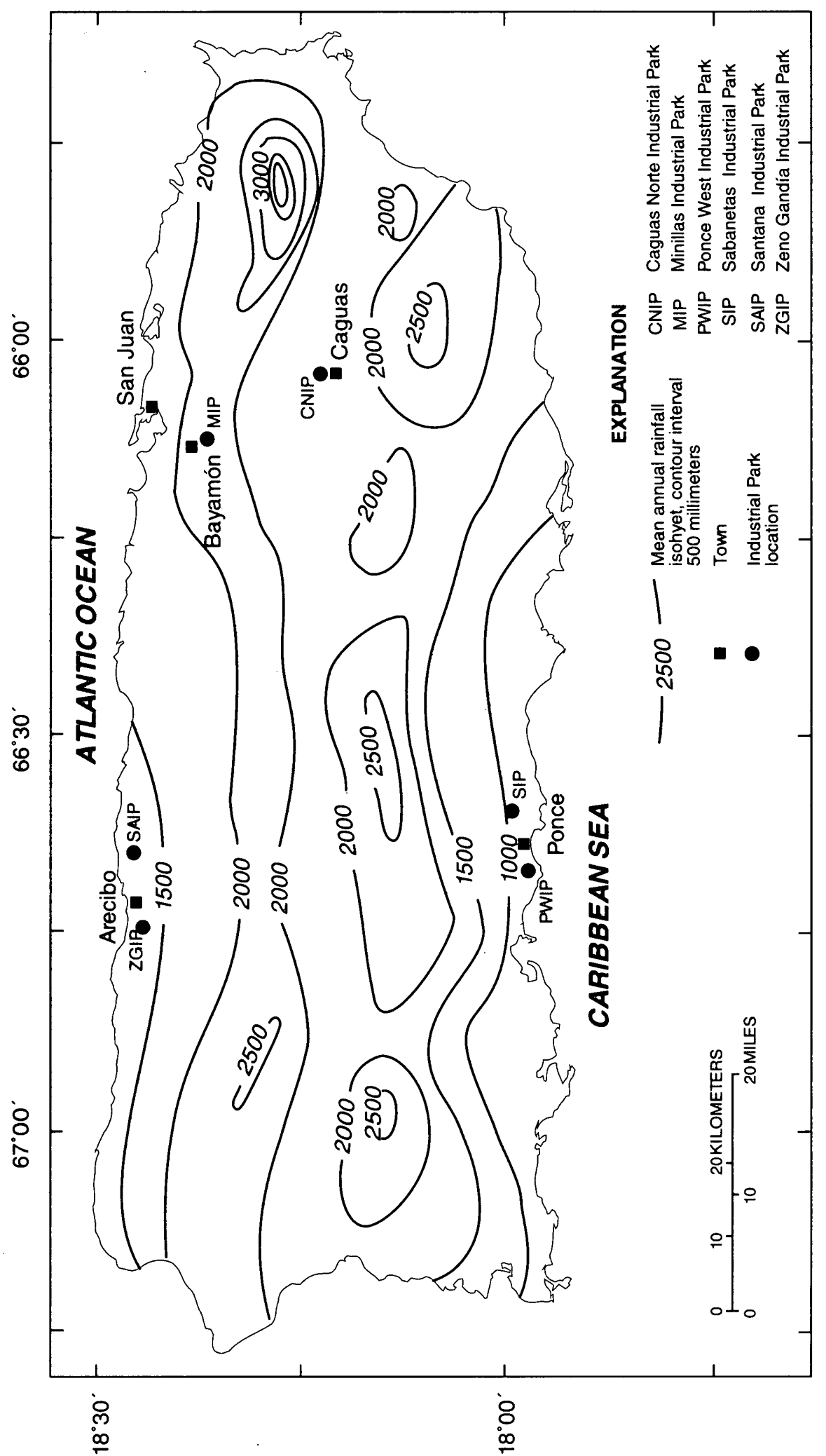

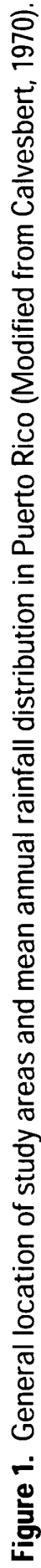


This report presents the data collected at ten drainage subareas within six industrial parks (fig. 1). Stormwater runoff was characterized at each of the drainage subareas during two storm events. Data collected include rainfall, site drainage, industrial activities in the study area, and stormwater discharge flow rates, volumes, and quality. These data were collected following methods similar to those required for a NPDES stormwater permit.

\section{METHODS OF DATA COLLECTION AND ANALYSIS}

Stormwater (SW) discharge characteristics were studied at ten drainage subareas from six industrial parks owned by PRIDCO. Data collection at each subarea consisted of rainfall volume and the flow rate and quality of SW discharge. The data were collected during two storm events at each drainage subarea with a continuous recording raingage, and a flow meter which was integrated to an automatic water sampler. The data-collection instruments were installed at, or as near as possible to, the outfalls of the storm sewer.

All the flow-rate data and the water samples were collected from inside the SW sewer system of the selected industrial parks. The probe of the flow meter and the intake of the sampler were placed at the bottom of the pipe of the corresponding sewer system. The automatic sampler and the raingage were installed above street level.

The flow meter consists of a pressure transducer that measures the height of the water surface in the pipe. The flow meter uses the height of the water surface and the configuration of the pipe to calculate the flow rate of the discharge. At each of the sampling points, the flow meter was calibrated according to manufacturer instructions and programmed to record flow-rate measurements every 5 minutes. The flowrate data were used to determine the SW discharge volumes during individual storm events and to determine the required sample volumes during the preparation of the flow-weighted composite samples.

Continuous rainfall data were collected with a tipping-bucket raingage. The raingage was connected to an automatic sampler. The automatic sampler was programmed to begin collecting stormwater samples when the required amount of rainfall, $2.54 \mathrm{~mm}$, had accumulated. Each storm event was preceded by at least 72 hours in which no storm event of a magnitude greater than $2.54 \mathrm{~mm}$ of rainfall had occurred.

Two types of SW samples were collected during each of the studied storm events-grab and discretegrab samples. Each grab sample was collected during the first 30 minutes of the storm runoff. Each discretegrab sample was collected every 20 minutes throughout the storm runoff for a maximum period of 3 hours. The discrete-grab samples were used to prepare a flow-weighted composite sample.

The flow-weighted composite sample was prepared using aliquots of the discrete-grab samples combined in proportion to flow. First, the flow rate at the time of the collection of the discrete-grab samples was determined using the data collected by the flow meter. The required volume from each discrete-grab sample to prepare the composite was calculated using the following formula (USEPA, 1991):

$$
V_{n}=\frac{V_{\text {max }} \cdot Q_{n}}{Q_{\text {max }}}
$$

where

$V_{n}$ is the volume required from discrete-grab sample $n$ to prepare the composite,

$V_{\text {max }}$ is the volume of sample collected at the highest flow rate,

$Q_{n}$ is the flow rate associated with sample $n$, and

$Q_{\max }$ is the highest flow rate at which a sample was collected.

Processed samples were sent for analysis to the USGS National Water Quality Laboratory at Arvada, Colorado. Biochemical oxygen demand (BOD)

analyses were performed at a local laboratory to meet the maximum holding time requirement of 24 hours for this analysis. 


\section{DESCRIPTION OF THE STUDY AREAS}

\section{General Rainfall Characteristics}

Rainfall in Puerto Rico varies notably across the island, ranging from less than $1,000 \mathrm{~mm}$ in the southern slopes to more than $4,000 \mathrm{~mm}$ in the eastcentral part of the island (fig. 1). The winds and the mountains of central Puerto Rico combine to produce an orographic rainfall distribution. In general, the north coast receives more rainfall than the south coast due to the rain shadow effect caused by the mountain range of central Puerto Rico.

The two rainfall producing mechanisms in Puerto Rico are easterly waves and cold fronts. Easterly waves usually are observed from May to November and cold fronts from November to April. Rainfall is well distributed throughout the year, though relative dry and wet seasons are observed. In general in the north the relative dry season extends from February to April, but in the south it begins during December (Calvesbert, 1970). Most rainfall is in the form of sudden showers that tend to be torrential, but generally last only from 15 to 30 minutes. Average annual rainfall at the studied areas ranged from less than $1,000 \mathrm{~mm}$ in the south to more than $2,000 \mathrm{~mm}$ in the north of Puerto Rico.

\section{Site Drainage}

\section{Sabanetas Industrial Park}

The Sabanetas Industrial Park (SIP) is located east of the urban center of the city of Ponce. The only hydrologic surface feature related to the study area is an unnamed intermittent creek that crosses the park (fig. 2). This unnamed creek receives SW discharges from the SIP. The creek flows eastward joining a drainage channel that eventually discharges to the Caribbean Sea.
The SIP occupies an area of approximately $260,000 \mathrm{~m}^{2}$ (fig. 2). Two drainage subareas within the SIP were selected for SW characterization based on the feasibility to collect flow and quality data, and relative segregation from activities not related to the park. Information describing the selected subareas, SIP 1 and SIP 2, is presented in table 1.

The SW flow pattern in SIP 1 (fig. 3) is mainly from the individual lots to the street. At the street, the $\mathrm{SW}$ is conveyed into the storm sewer system by storm drains located along the street. In the area comprised by lots 1 to 5 and 14 to 17 , the SW runs directly to storm drains and into the storm sewer system.

A sanitary sewer pump station located within the boundaries of SIP 1 has a by-pass connection to the storm sewer system. The by-pass outlet is located about $20 \mathrm{ft}$ upgradient from the outfall of SIP 1. The occurrence of a discharge of untreated wastewater by the by-pass connection to the storm sewer was documented during a storm event (April 11, 1995) in which samples were collected.

The SW flow pattern in SIP 2 is mainly from the individual lots to the streets (fig. 4). Upon reaching the street, the SW flows into the park storm sewer system. An exception to the flow pattern described above occurs on the area comprised by lots 29 and 30, and on the area comprised by lots 21,23 , and 31 . In lots 29 and 30 , the stormwater from sections of the roof and the grassed area south of the building is conveyed and discharged directly to the storm sewer system. During a site visit on March 30, 1995, to the area comprised by lots 29 and 30, it was observed that hazardous materials were being stored uncovered and exposed to rainfall at an area located north of the building (fig. 4). A continuous non-stormwater discharge to the storm sewer was observed in the storm drain northeast of lot 21, 23, and 31. As in SIP 1, the stormwater from SIP 2 is discharged to the unnamed creek. 


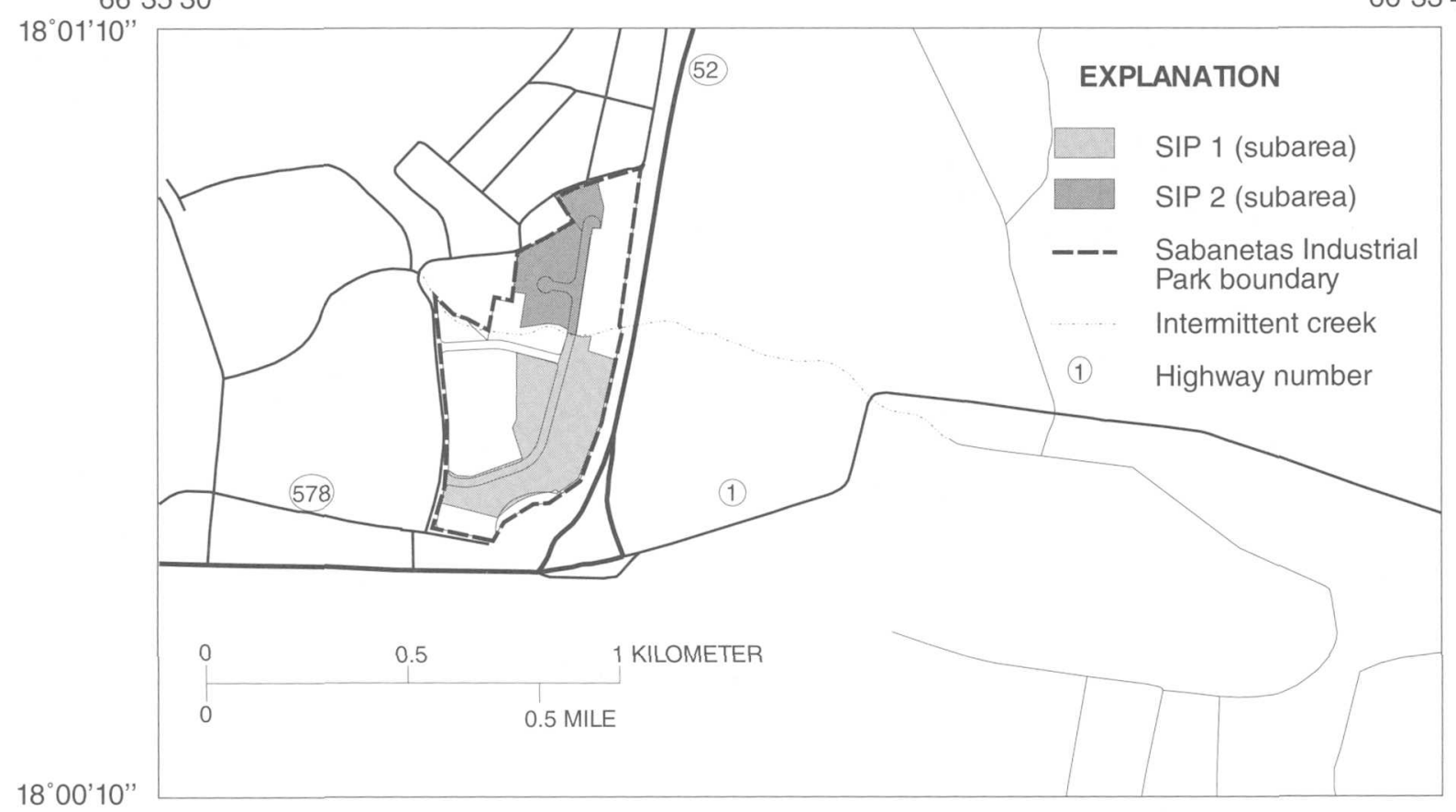

Figure 2. Location of the Sabanetas Industrial Park (SIP), Ponce, Puerto Rico. 


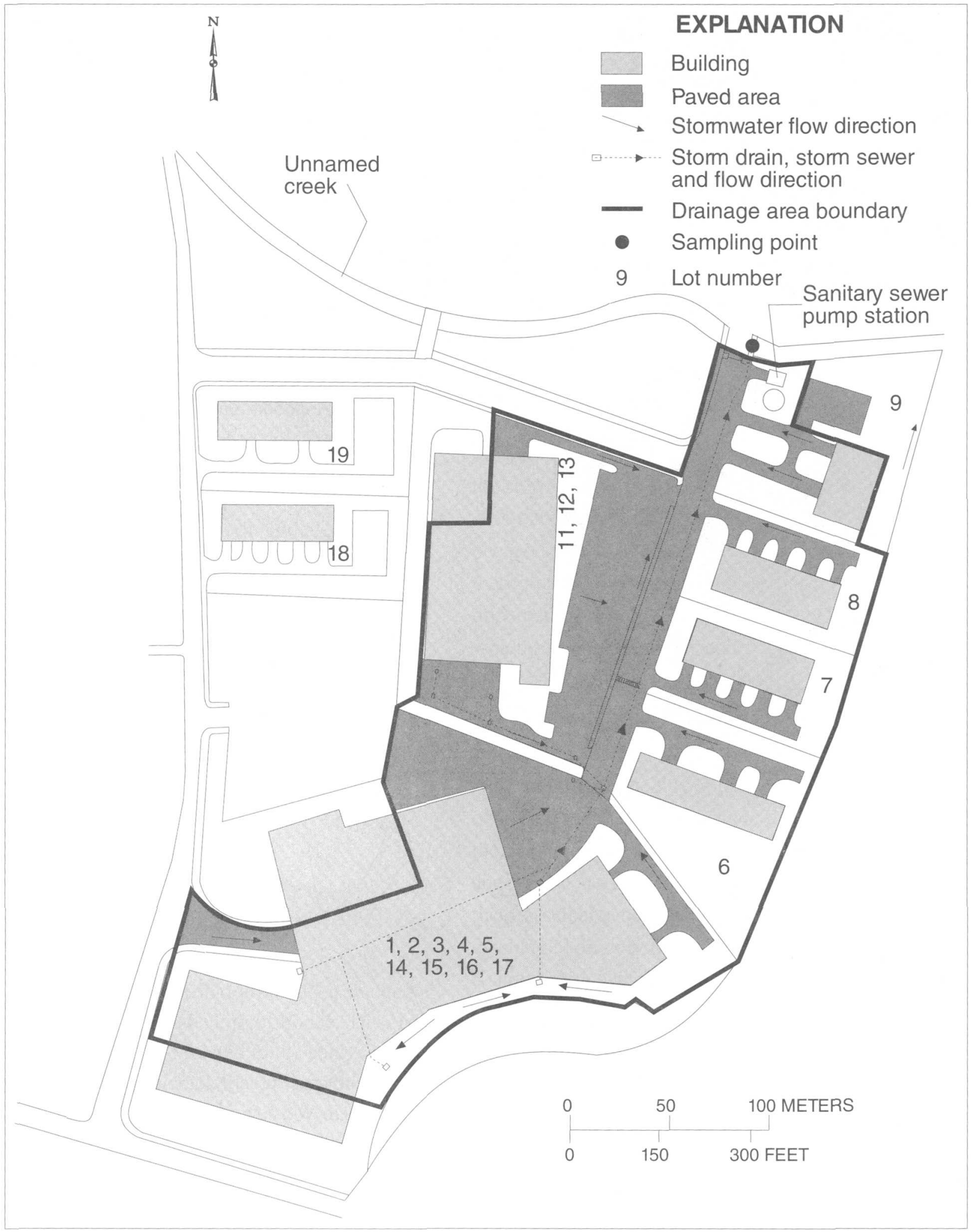

Figure 3. Site drainage for subarea SIP 1. 


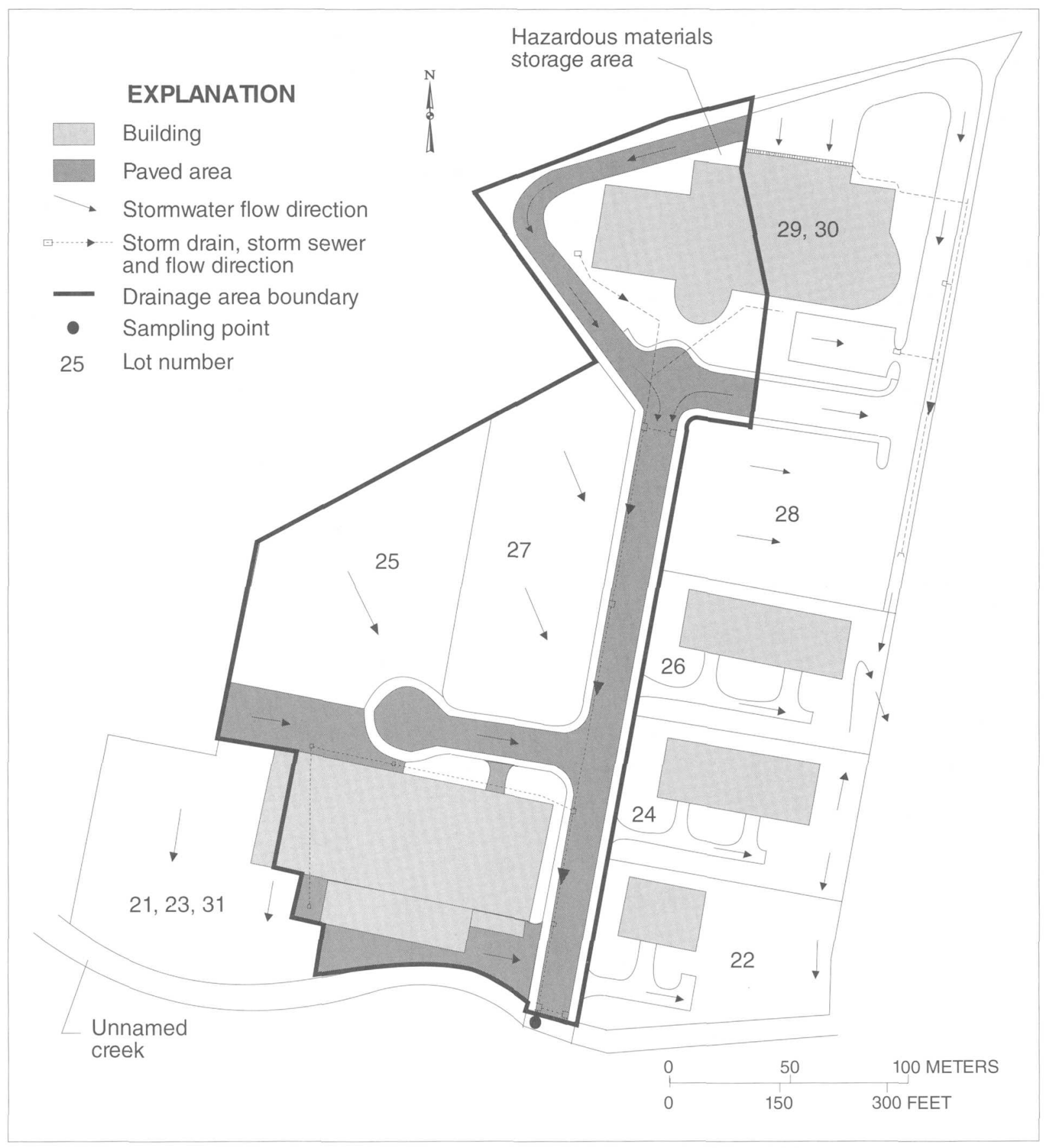

Figure 4. Site drainage for subarea SIP 2. 


\section{Ponce West Industrial Park}

The Ponce West Industrial Park (PWIP) is located west of the city of Ponce in southern Puerto Rico (fig. 5). An intermittent creek, Quebrada del Agua, is located north of the PWIP; however, this creek does not receive contribution from the SW discharges of the PWIP. The PWIP occupies an area of approximately $270,000 \mathrm{~m}^{2}$. Two of the drainage subareas, PWIP 1 and PWIP 2 (fig. 5), within the park were selected for characterization of the stormwater discharges based in the feasibility to collect the flow and quality data. Information for each subarea is presented in table 1.
The SW flow pattern in PWIP 1, which is comprised by 14 lots, is from the individual lots to the streets. The stormwater is conveyed by storm drains along the street into the storm sewer system. The outfall for PWIP 1 discharges the SW on open ground south of Highway 2 (fig. 6). A natural channel disappears approximately $50 \mathrm{~m}$ south from the outfall, which indicates that the stormwater spreads over the ground and infiltrates.

PWIP 2 (fig. 7) is comprised by five industrial lots. The stormwater flow pattern is similar as Subarea 1: the SW flows from the individual lots to the street, where it is conveyed by the storm sewer to the outfall. The outfall for PWIP 2 discharges on open ground south of Highway 2 and infiltrates.

Table 1. Estimated area covered by impervious surfaces and total area drained by each outfall in the studied subareas of the selected industrial parks

[ $\mathrm{m}^{2}$, square meters; SIP, Sabanetas Industrial Park; PWIP, Ponce West Industrial Park; MIP, Minillas Industrial Park; CNIP, Caguas Norte Industrial Park; SAIP, Sabanetas Industrial Park; ZGIP, Zeno Gandía Industrial Park]

\begin{tabular}{llcrl}
\hline Subarea & $\begin{array}{c}\text { Outfall location } \\
\text { (Latitude-Longitude) }\end{array}$ & $\begin{array}{c}\text { Area of } \\
\text { impervious } \\
\text { surface }\left(\mathrm{m}^{2}\right)\end{array}$ & $\begin{array}{c}\text { Total area } \\
\text { drained }\left(\mathrm{m}^{2}\right)\end{array}$ & Receiving water body \\
\hline SIP 1 & $18^{\circ} 00^{\prime} 45^{\prime \prime}-66^{\circ} 34^{\prime} 56^{\prime \prime}$ & 61,300 & 85,000 & Unnamed creek \\
SIP 2 & $18^{\circ} 00^{\prime} 46^{\prime \prime}-66^{\circ} 34^{\prime} 57^{\prime \prime}$ & 18,800 & 46,000 & Unnamed creek \\
PWIP 1 & $17^{\circ} 59^{\prime} 26^{\prime \prime}-66^{\circ} 38^{\prime} 55^{\prime \prime}$ & 87,900 & 129,000 & None \\
PWIP 2 & $17^{\circ} 59^{\prime} 23^{\prime \prime}-66^{\circ} 39^{\prime} 00^{\prime \prime}$ & 12,100 & 32,500 & None \\
MIP 1 & $18^{\circ} 22^{\prime} 42^{\prime \prime}-66^{\circ} 08^{\prime} 22^{\prime \prime}$ & 86,500 & 143,000 & Unnamed creek \\
MIP 2 & $18^{\circ} 22^{\prime} 42^{\prime \prime}-66^{\circ} 08^{\prime} 28^{\prime \prime}$ & 65,600 & 112,000 & Unnamed creek \\
CNIP & $18^{\circ} 14^{\prime} 56^{\prime \prime}-66^{\circ} 02^{\prime} 10^{\prime \prime}$ & 82,500 & 124,000 & Río Bairoa \\
SAIP & $18^{\circ} 27^{\prime} 33^{\prime \prime}-66^{\circ} 39^{\prime} 43^{\prime \prime}$ & 7,300 & 82,000 & Ciénaga Tiburones \\
ZGIP 1 & $18^{\circ} 27^{\prime} 32^{\prime \prime}-66^{\circ} 44^{\prime} 35^{\prime \prime}$ & 169,000 & ${ }^{1} 203,000$ & Unnamed creek \\
ZGIP 2 & $18^{\circ} 27^{\prime} 32^{\prime \prime}-66^{\circ} 44^{\prime} 35^{\prime \prime}$ & 53,000 & 279,000 & Unnamed creek \\
\hline
\end{tabular}

\footnotetext{
${ }^{1}$ This area includes approximately $107,000 \mathrm{~m}^{2}$ external to the ZGIP.

2 This area includes approximately $14,000 \mathrm{~m}^{2}$ external to the ZGIP.
} 


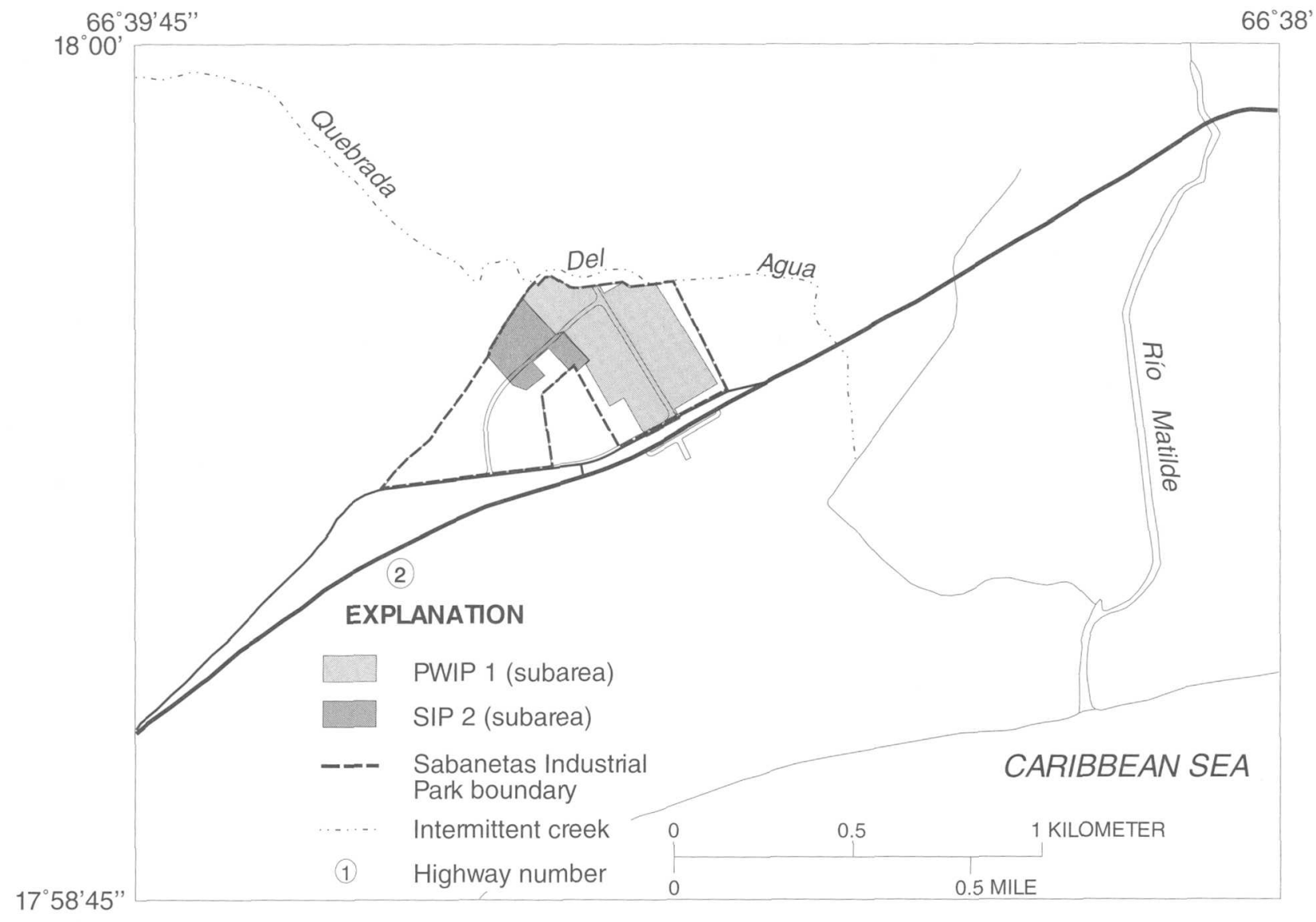

Figure 5. Location of the Ponce West Industrial Park (PWIP), Ponce, Puerto Rico. 


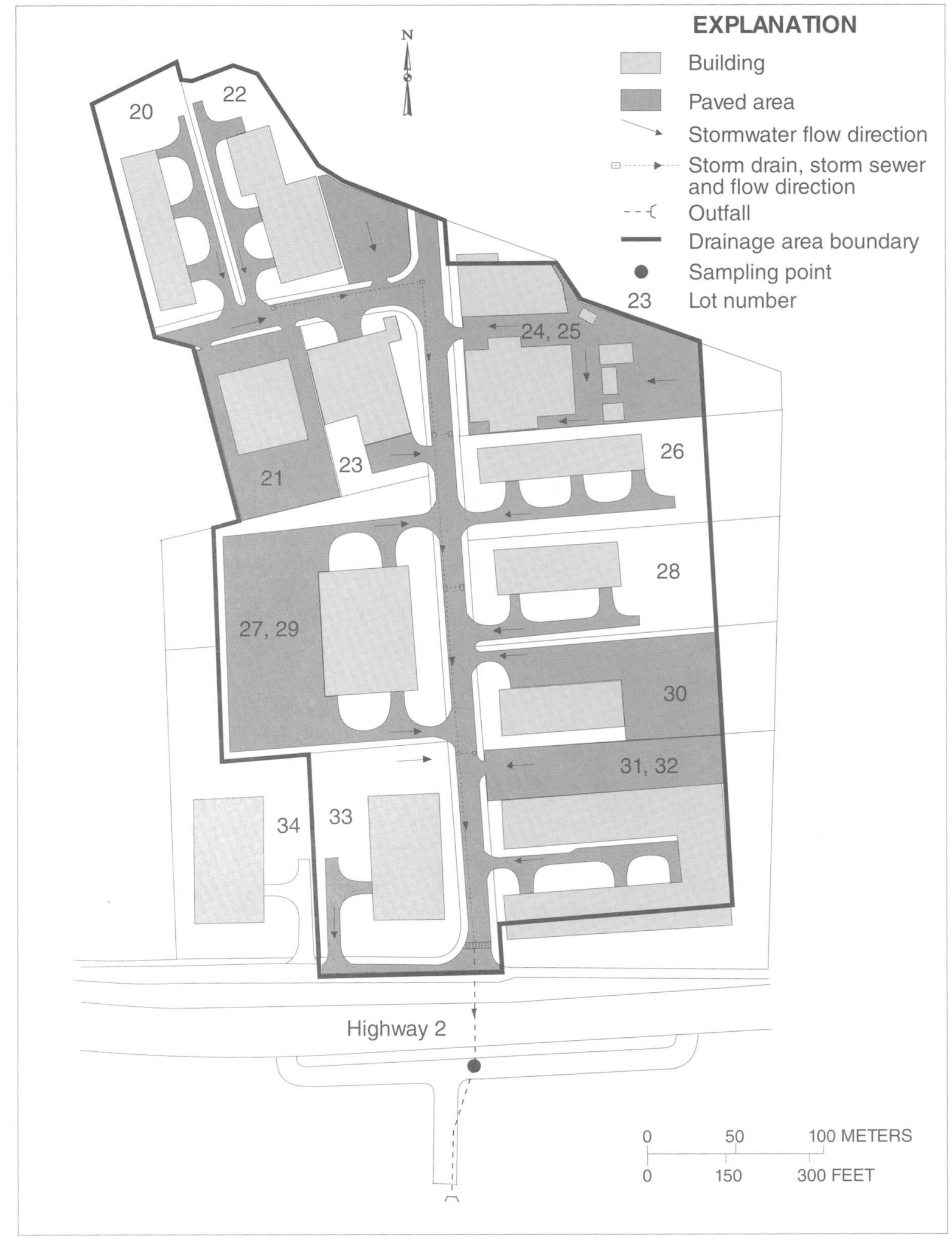

Figure 6. Site drainage for subarea PWIP 1. 


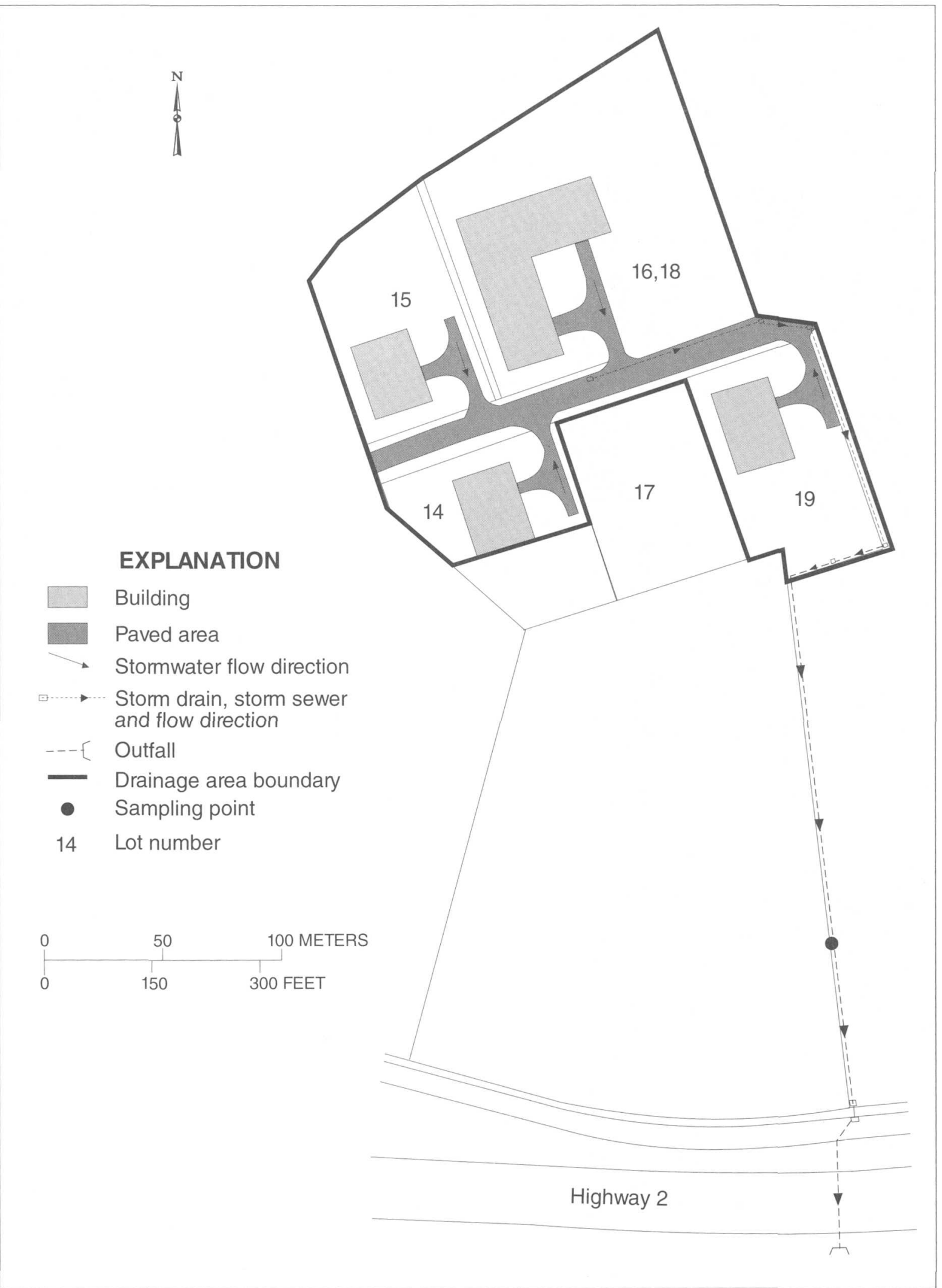

Figure 7. Site drainage for subarea PWIP 2. 


\section{Minillas Industrial Park}

The Minillas Industrial Park (MIP) is located southeast of the urban center of the city of Bayamón in northern Puerto Rico (fig. 8). The hydrologic surface features related to the MIP are an unnamed intermittent creek and the Río de Bayamón. The unnamed creek divides the northern and southern sections of the MIP and discharges to the Río de Bayamón. The Río de Bayamón borders the MIP on the east and flows north to the Atlantic Ocean.

The MIP occupies an area of approximately $780,000 \mathrm{~m}^{2}$. Two of the drainage subareas, MIP 1 and MIP 2 (fig. 8), were selected for SW characterization based on the feasibility to collect the water quality and flow data, and to segregate the areas from activities not related to the industrial park.

MIP 1 is located in the southern section of the park and is comprised of 33 lots (fig. 9). The SW flow pattern is mainly from the individual lots to the streets, where the $\mathrm{SW}$ is conveyed into the storm sewer by storm drains. Exceptions to this flow pattern are found in lots 48,49 to 51 , and 77. At lot 48 the SW is collected by a concrete channel located parallel to the boundary with lots 58 and 57. At the southeastern corner of lot 48 , the $\mathrm{SW}$ is conveyed into the storm sewer. The flow pattern at lots 49 to 51 is towards the east, where it flows through a pipe located within lots 55 and 56. The SW from the southeast section of lot 77 is collected by a storm drain and discharged directly into the storm sewer. The outfall from the storm sewer that conveys the runoff from MIP 1 discharges to the unnamed creek north of the subarea.

MIP 2 (fig. 10) is located at the northern section of the park and is comprised of 11 lots. The SW flow pattern is mainly from the individual lots to the streets, where the stormwater is conveyed into the storm sewer by storm drains. Exceptions to this flow pattern are found in sections from lots $24 \mathrm{~A}, 24 \mathrm{~B}, 25,32$, and 33. At the northern section of lot 25 the $\mathrm{SW}$ is collected by a concrete channel which discharges to the storm sewer. The SW from the southern section of lot 25 is collected by a storm drain and discharged to a concrete channel that traverses lots $24 \mathrm{~A}$ and $24 \mathrm{~B}$.
This concrete channel discharges to an underground pipe that also conveys the SW from lots 32 and 33 . The outfall of the storm sewer that conveys the SW from MIP 2 discharges to the unnamed creek that crosses the MIP.

\section{Caguas Norte Industrial Park}

The Caguas Norte Industrial Park (CNIP) is located in the northern part of the city of Caguas, in east central Puerto Rico (fig. 11). The Río Bairoa, which flows eastward, is the receiving water body of the SW discharges from the CNIP.

The CNIP (fig. 12) occupies an area of approximately $200,000 \mathrm{~m}^{2}$ and is divided into 22 industrial lots. Information about the drainage of the studied subarea is presented in table 1 .

The SW flow pattern at the CNIP is mainly from the individual lots to the streets. At the streets the SW is conveyed into the storm sewer by storm drains. Exceptions to the flow pattern described above occurs at the area comprised by lots 9 and 11 , and at lot 19 .

At the area comprised by lots 9 and 11, a concrete channel conveys the SW from the western section of this area and from sections of lot 13. A similar channel was observed at the southern side of lot 19. These channels discharge the SW to the street. Continuous non-stormwater discharge were measured at CNIP during the sampling period. The storm sewer from the CNIP discharges to the municipal storm sewer at Highway 1, which eventually discharges into the Río Bairoa (fig. 11). 


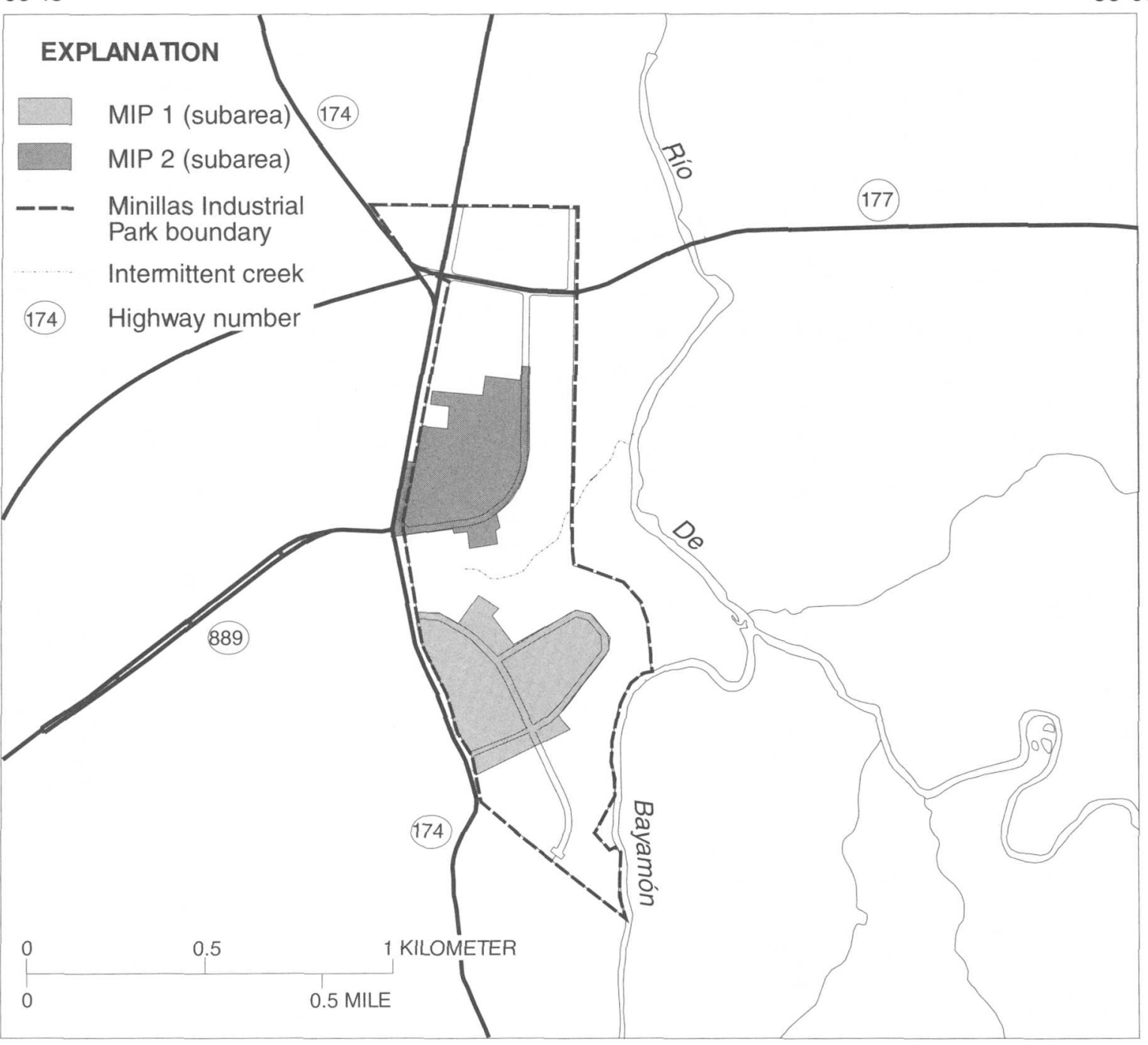

$18^{\circ} 22^{\prime}$

Figure 8. Location of the Minillas Industrial Park (MIP), Bayamón, Puerto Rico. 


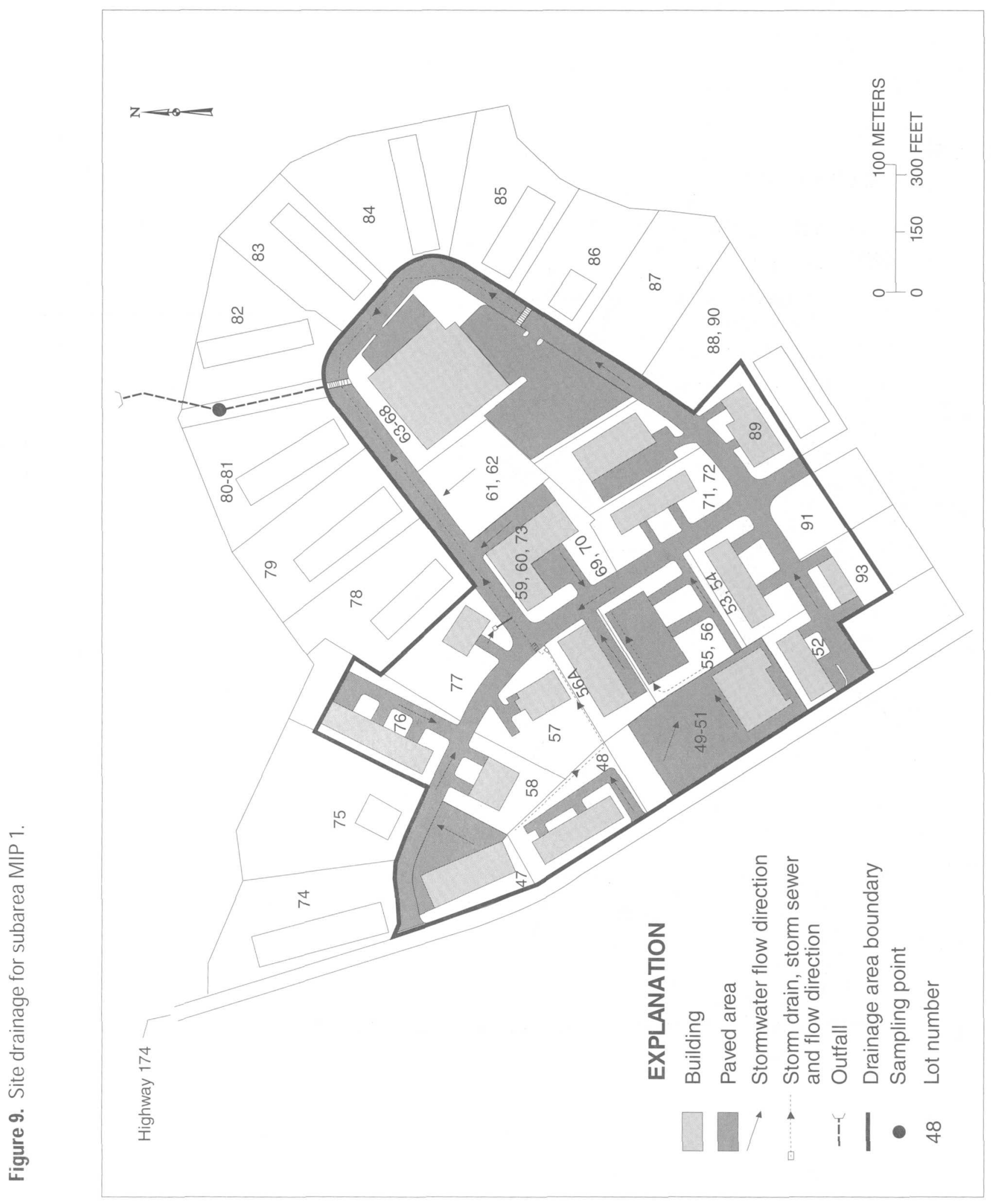




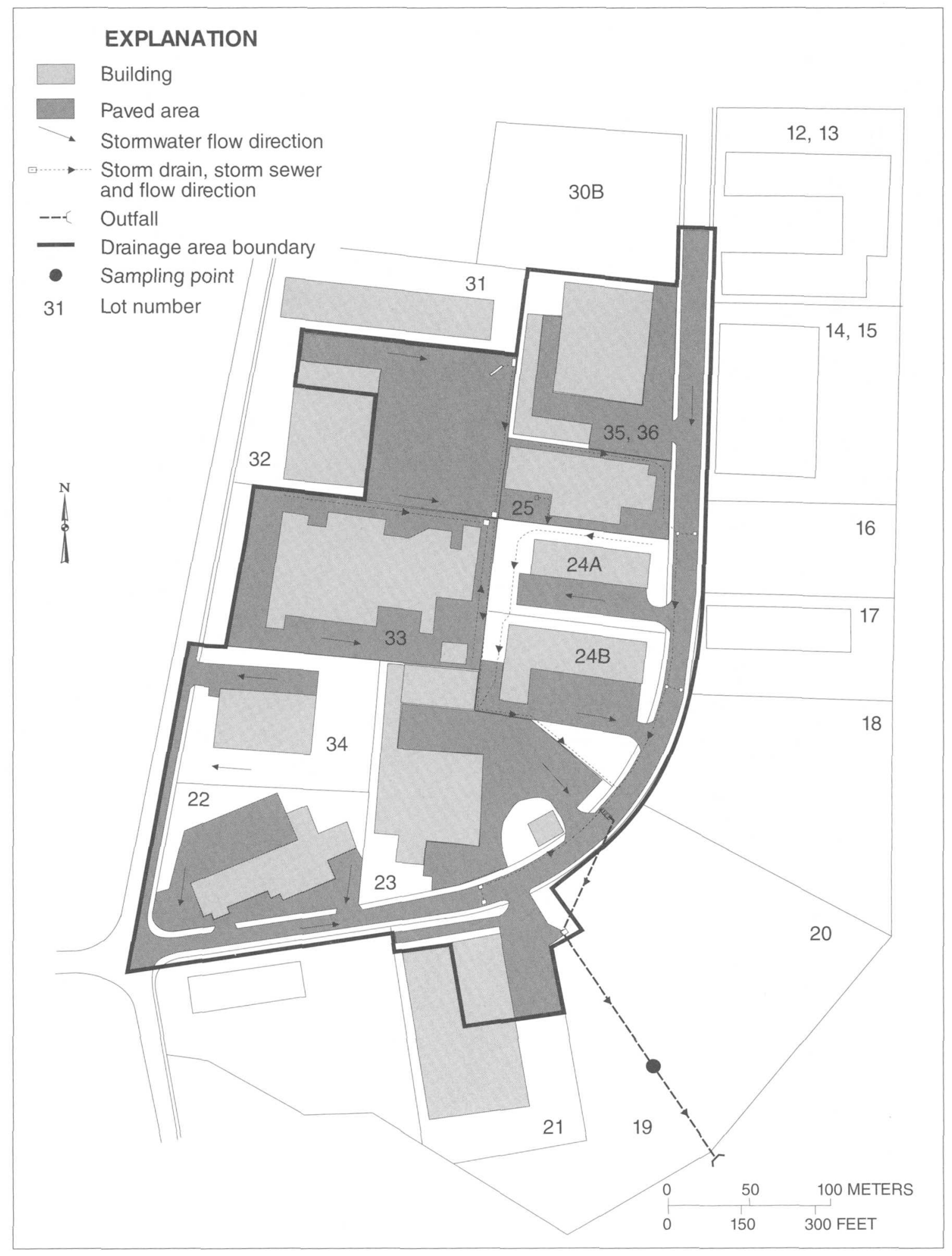

Figure 10. Site drainage for subarea MIP 2. 


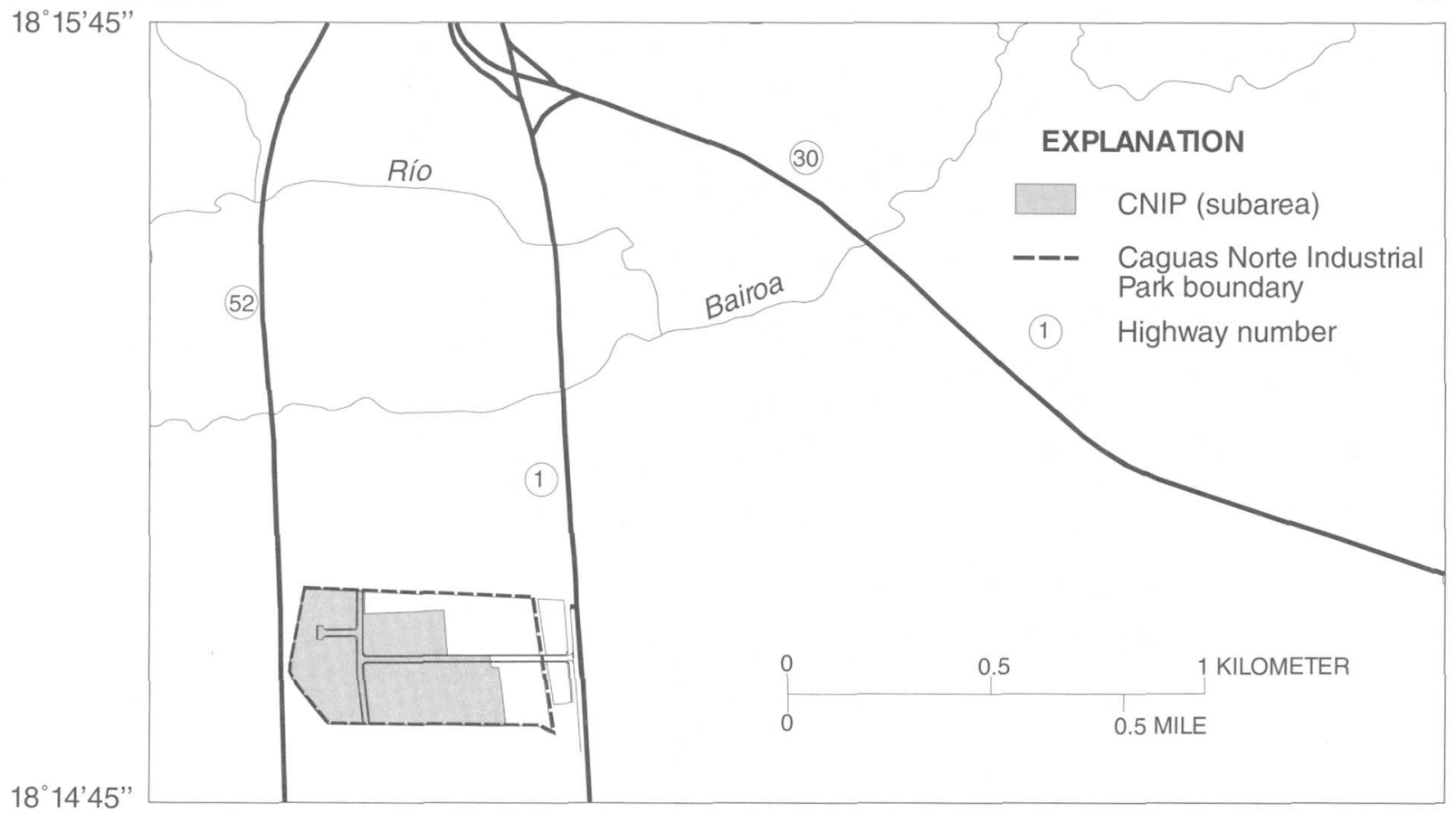

Figure 11. Location of the Caguas Norte Industrial Park (CNIP), Caguas, Puerto Rico. 


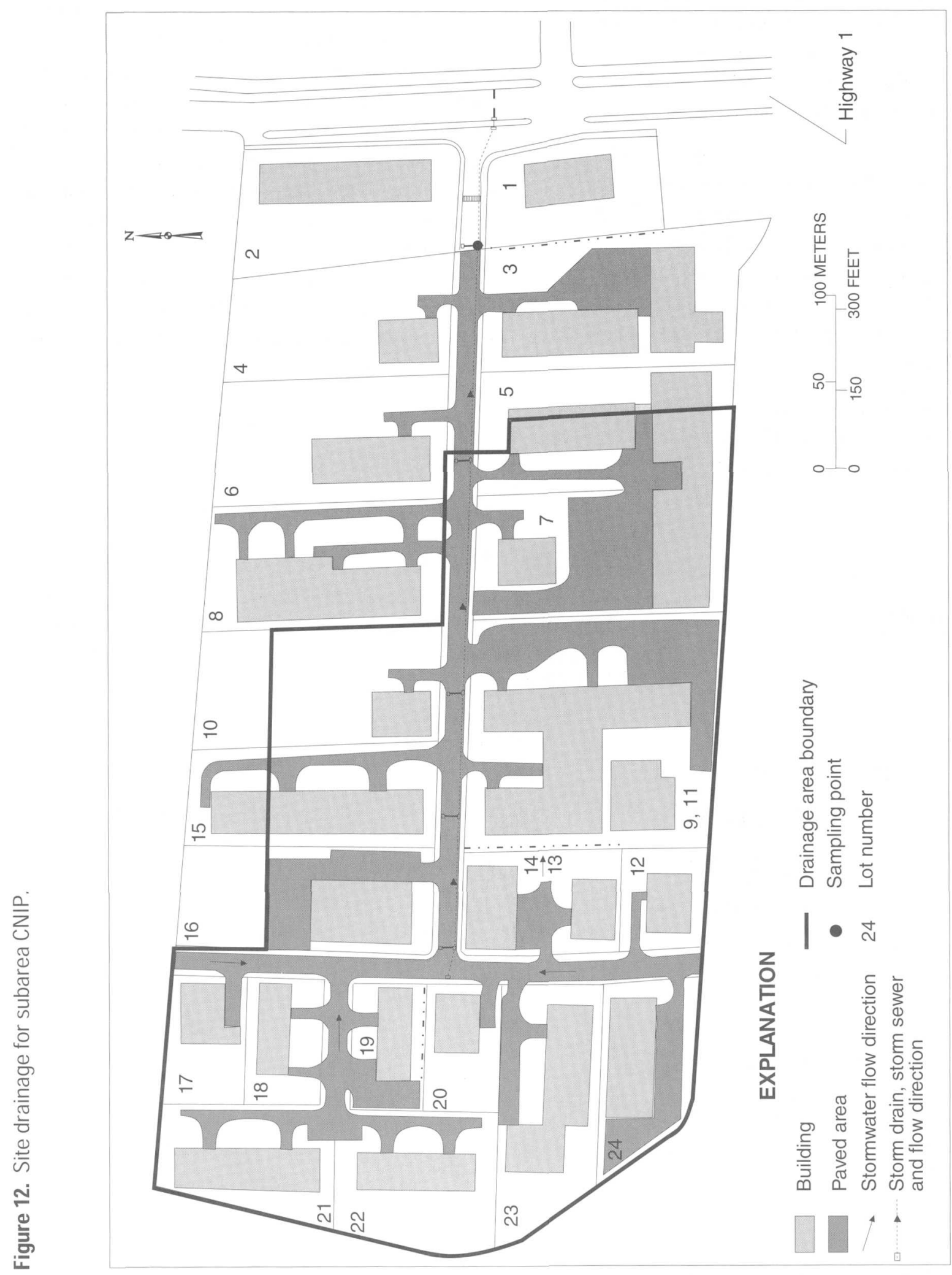




\section{Santana Industrial Park}

The Santana Industrial Park (SAIP) is located east of the city of Arecibo, in northern Puerto Rico (fig. 13). The hydrologic surface feature related to the SAIP is the Ciénaga Tiburones, which is a wetland area located north of the park.

The SAIP occupies an area of approximately $390,000 \mathrm{~m}^{2}$ and is divided in two sections. A subarea (fig. 14) located at the northern section of the park was selected for characterization even though no industrial activity was taking place at the time of the study. The data collected from this subarea will be used to compare the data collected from other parks which are fully developed.

The SW flow pattern in the selected subarea (fig. 14) is from the individual lots to the streets, where it is conveyed into the storm sewer by storm drains.
The outfall of SAIP discharges to the Ciénaga Tiburones. Continuous flow of water was measured at the sampling point during the study. A cyclic pattern was observed from the flow data, with the highest discharge occurring during the night. Apparently the water flowing in the storm sewer is caused by the infiltration of ground water due to the proximity of the water table to the land surface. The elevation of the ground water at the area is estimated to be from 1 to $1.5 \mathrm{~m}$ above mean sea level (Fernando GómezGómez, USGS, oral commun., 1997). The elevation of the storm sewer at the sampling station is about 1.5 meters above mean sea level. The cyclic flow pattern may be caused by the evapotranspiration occurring during daytime.

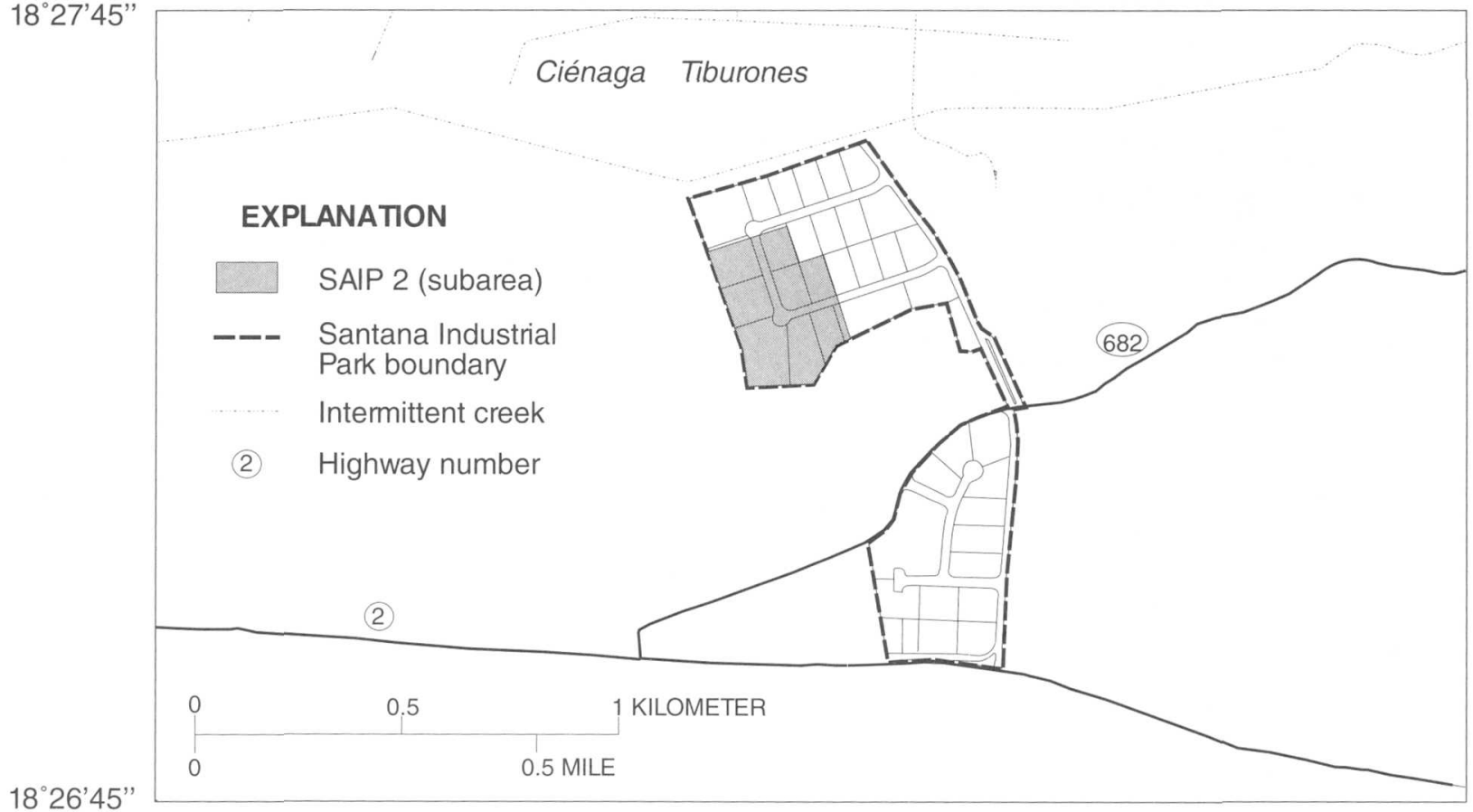

Figure 13. Location of the Santana Industrial Park (SAIP), Arecibo, Puerto Rico. 


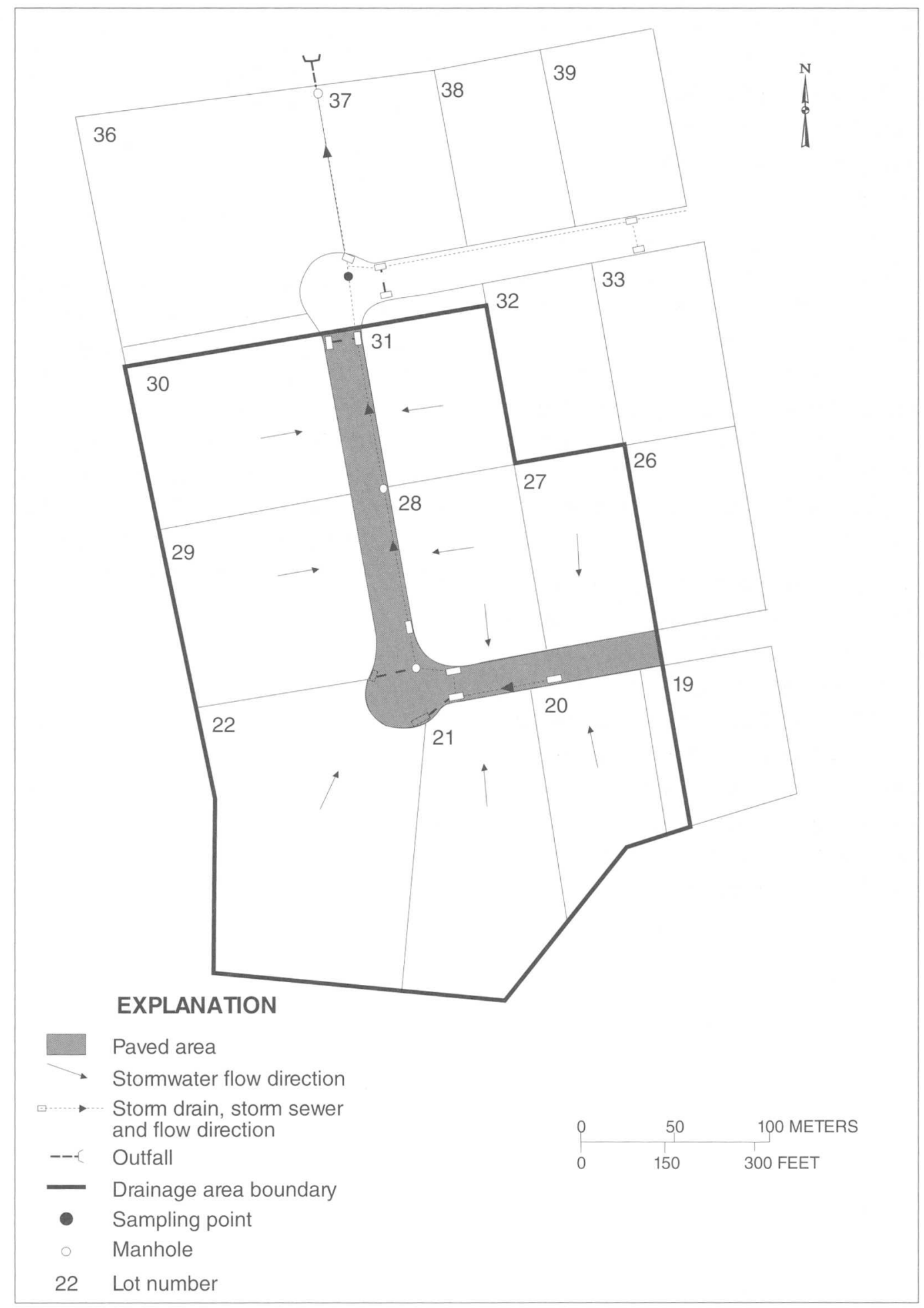

Figure 14. Site drainage for subarea SAIP. 


\section{Zeno Gandia Industrial Park}

The Zeno Gandía Industrial Park (ZGIP) is located southwest of the urban center of the city of Arecibo, in northern Puerto Rico (fig. 15). The hydrologic surface feature related to the ZGIP is an unnamed intermittent creek, which is located southeast of the park. This creek eventually discharges to the Río Santiago.

The ZGIP occupies an area of approximately $330,000 \mathrm{~m}^{2}$. Two subareas, ZGIP 1 and ZGIP 2 (fig. 15), were selected for characterization based in the feasibility to collect the water flow and quality data. It was not possible to segregate these areas from activities not related to the industrial park. Both of the selected subareas receive substantial contributions of SW from a residential area north of the park. Information describing the selected subareas is presented in table 1.

The SW flow pattern in ZGIP 1 (fig. 16) is mainly from the individual lots to the street, where its conveyed into the storm sewer by storm drains. Exceptions to the flow pattern described above were observed at lot 40 and lot 44 . An outlet to the storm sewer, not shown on the storm sewer plans, was observed at the storm drain located in front of lot 40 . The origin of this outlet is unknown. Lot 44 has a storm drain in the north east corner of the lot, which discharges directly to the storm sewer.
In addition to the SW runoff produced at ZGIP 1, contribution occurs from outside of the park. The storm sewer, which conveys the SW from a section of the residential area north of the park, discharges at the storm drain located in front of the boundary of lots 36 and 38 .

The SW flow pattern at the ZGIP 2 (fig. 17) is mainly from the individual lots to the streets. At the street the SW is conveyed by storm drains into the storm sewer. An exception to this flow pattern are two concrete channels at the northwest section of the area comprised by lots $6,11,12,17-19$. One of these channels collects the $\mathrm{SW}$ from the northwest section of the lots and the other conveys the SW from a residential area northwest of ZGIP 2. The channels join and discharge directly to a storm drain located in front of the east boundary of lot 21A. The outfalls for the storm sewer from ZGIP 1 and ZGIP 2 discharge to the intermittent creek located southeast of the park. This creek flows into Río Santiago. 


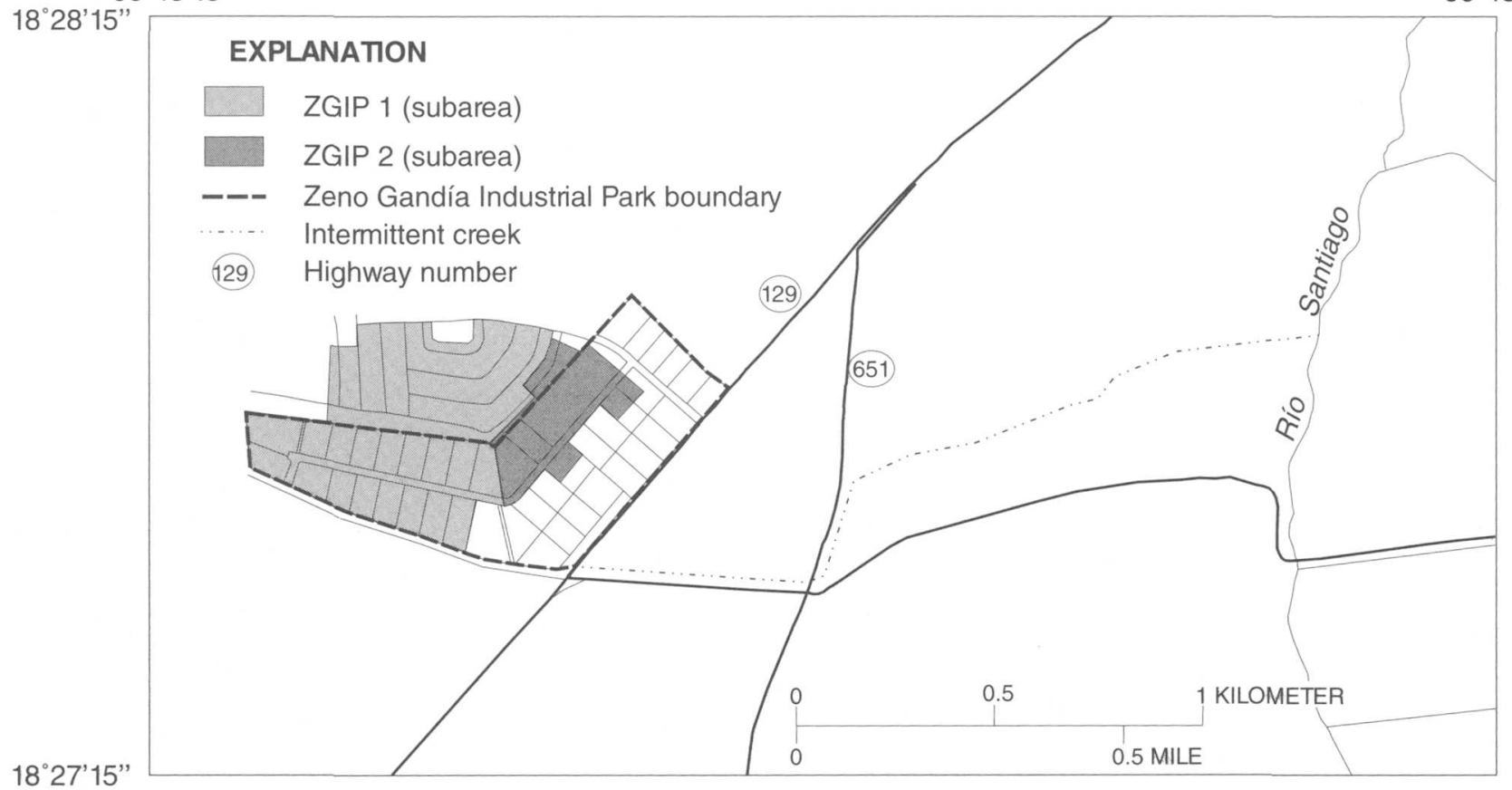

Figure 15. Location of the Zeno Gandia Industrial Park (ZGIP), Arecibo, Puerto Rico. 


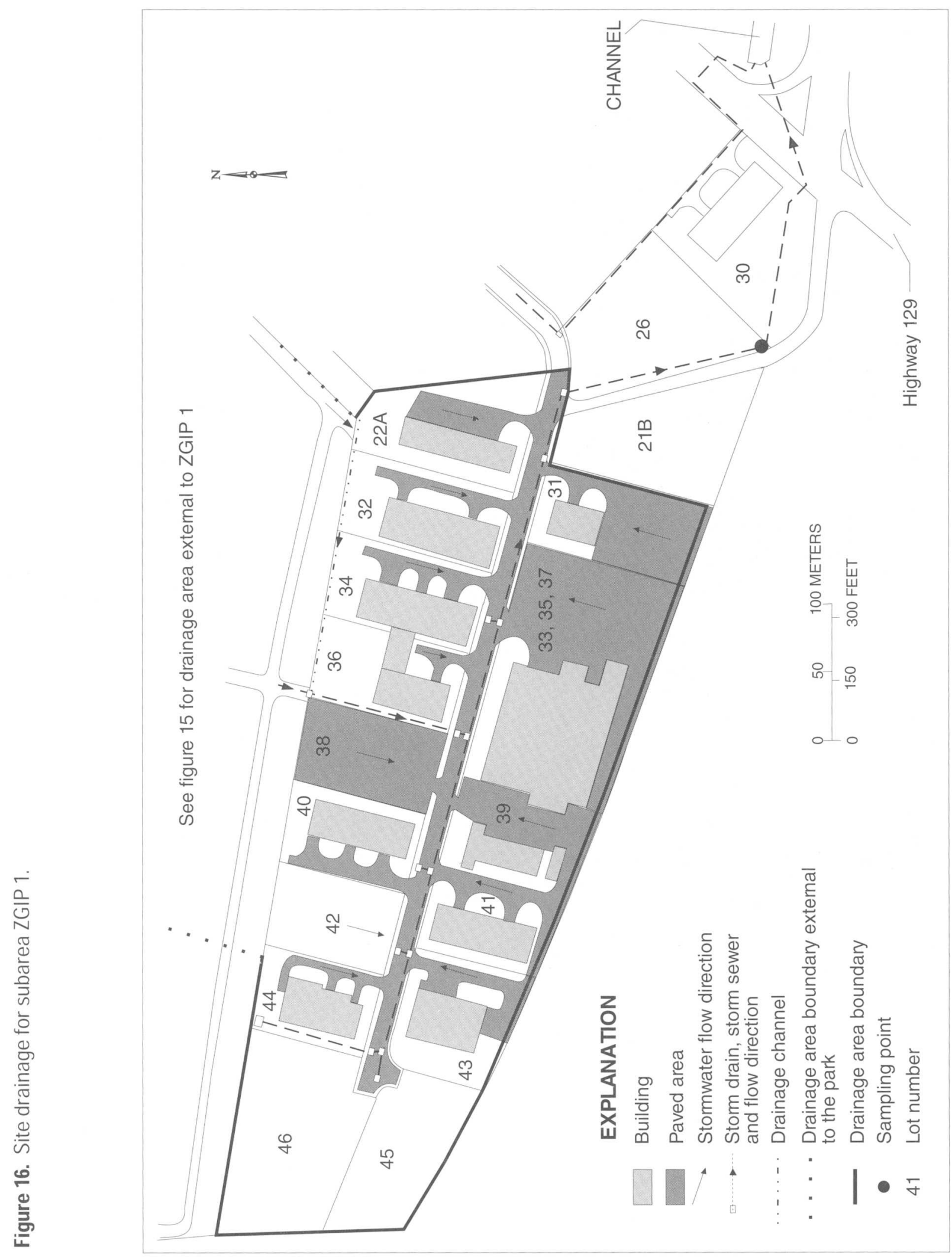




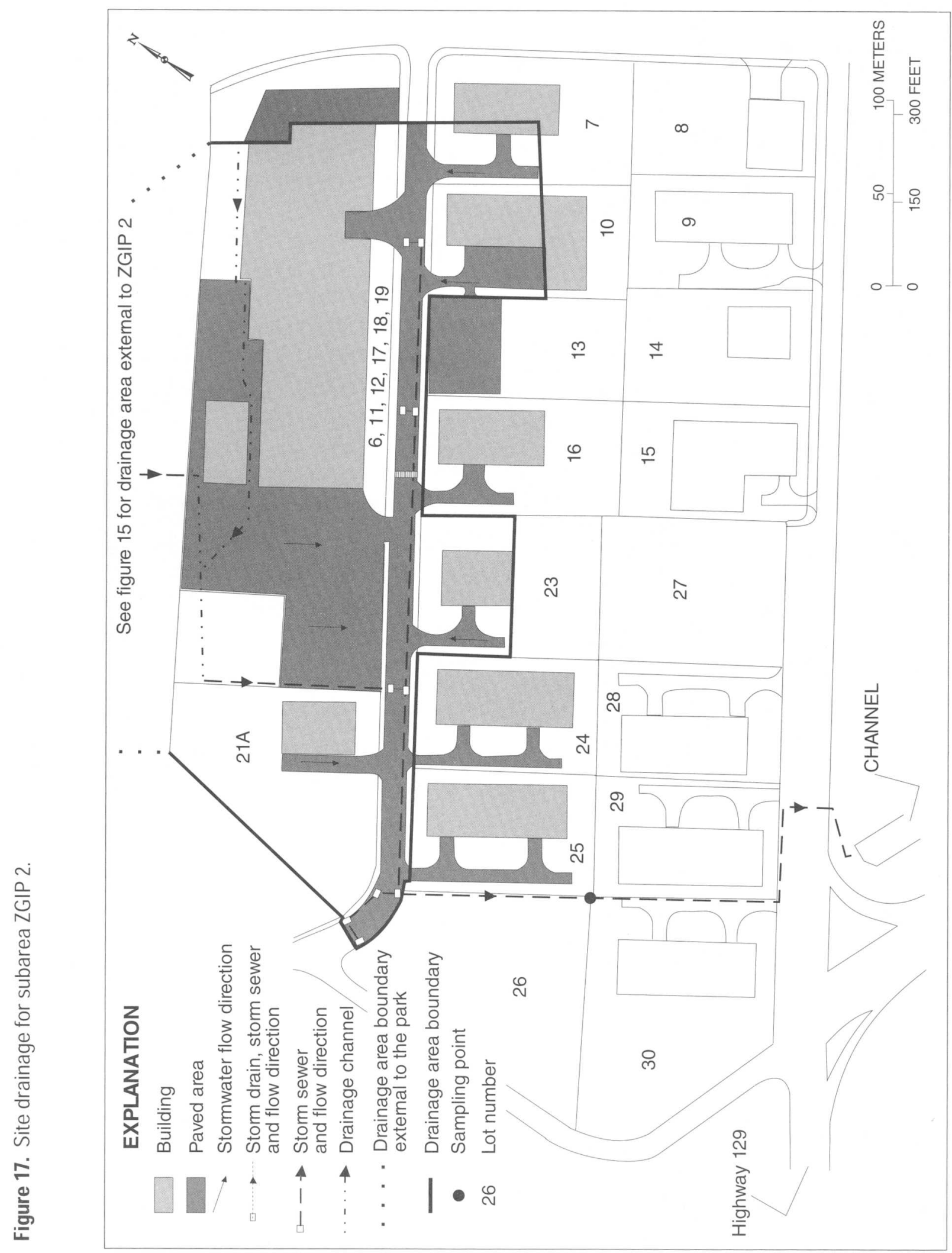




\section{FLOW RATES AND VOLUMES OF THE STORMWATER DISCHARGE}

Selected characteristics of the storm events studied during this investigation are presented in table 2. The information presented includes the dates of the storm events, duration of each storm, the duration of each sampling period, the total rainfall, the duration of the dry period preceding each event, the maximum flow rates, and the total flow volumes.

The duration of the sampling period extends from the time the grab sample was collected to the time the last discrete-grab sample was collected. The U.S. Environmental Protection Agency (1991) guidelines establish that the discrete-grab samples should be collected during the entire runoff or at least the first 180 minutes of the event.

The dry period preceding the event is the time from the last storm event with more than $2.54 \mathrm{~mm}$ of rainfall to the beginning of the studied storm event. The sampled storm event should be preceded by at least 72 hours of dry period. The total flow volumes presented in table 2 were estimated by multiplying each of the flow rate measurements by the time interval that represents the portion of the sampling period duration associated with the measurement (5 minutes), and then adding all such partial volumes (U.S. Environmental Protection Agency, 1991).

Data collected showed that 8 of the 18 studied storm events lasted 30 minutes or less and had a volume of rainfall of less than $10 \mathrm{~mm}$. The runoff calculated for each storm event ranged from 0.13 to $15.9 \mathrm{~mm}$. Runoff to rainfall ratios ranged from 0.04 to 0.82 .

\section{QUALITY OF STORMWATER DISCHARGES}

A total of 42 stormwater samples were collected at the sampling points near the outfalls that drain the subareas of the selected industrial parks. As mentioned previously, grab and flow-weighted composite samples were analyzed for each storm event characterized.
Each sample was analyzed for BOD, chemical oxygen demand (COD), total organic carbon (TOC), total suspended solids (TSS), ammonia plus organic nitrogen (TKN), nitrate plus nitrite as nitrogen, total phosphorous (TP), and $\mathrm{pH}$. In addition to these constituents, the grab samples were analyzed for oil and grease. Also, the samples collected during the two events at the CNIP and the samples from one event at the ZGIP 1 were analyzed for metals. The results of the laboratory analyses are presented in tables 3 and 4 . The results are also presented graphically in figure 18 , where letters $\mathrm{A}, \mathrm{B}$, and $\mathrm{C}$ after the subarea identification represent the first, second, and third sample collected, respectively. Extremely high concentrations of BOD, COD, and TOC where obtained at subareas SIP 2, MIP 2, CNIP, and ZGIP 1. High concentrations of TKN and TP were obtained at SIP 2, CNIP, and ZGIP1. The high concentrations of these constituents resemble those of waste discharges rather than stormwater runoff.

Figure 18 also gives the 25 and 75 percentile values of TP and total nitrogen (TN, the sum of TKN and nitrate plus nitrite concentrations) from composite samples collected at two urban drainage areas in the Lago de Cidra basin (Ramos-Ginés, 1997), one of which has sanitary sewers (URBS) and the other is unsewered (URBU). Concentration of TP from URBS is exceeded at SIP 2 and CNIP. Concentrations from samples at CNIP also exceeded the TP values from URBU. Phosphorus is a major component of many commercial cleaning preparations, body wastes, and food residue, thus an indicator of wastewater discharges. TN values from URBS were exceeded by the concentrations from most of the industrial subareas; however, URBU values were exceeded only by values for CNIP and ZGIP1.

Figure 18 includes the benchmark (BMRK) concentrations established by USEPA (table 5) for some of the analyzed constituents. The benchmark concentrations are values above which USEPA has determined that a stormwater discharge could potentially impair or contribute to impairing water quality or affect human health from ingestion of water or fish (U.S. Environmental Protection Agency, 1995). 
Table 2. Characteristics of the studied storm events at selected industrial parks in Puerto Rico

[SIP, Sabanetas Industrial Park; PWIP, Ponce West Industrial Park; MIP, Minillas Industrial Park; CNIP, Caguas Norte Industrial Park; SAIP, Santana Industrial Park; ZGIP, Zeno Gandía Industrial Park]

\begin{tabular}{|c|c|c|c|c|c|c|c|}
\hline Subarea & $\begin{array}{c}\text { Date of } \\
\text { storm event }\end{array}$ & $\begin{array}{l}\text { Duration of } \\
\text { storm, in } \\
\text { minutes }\end{array}$ & $\begin{array}{l}\text { Duration of } \\
\text { sampling } \\
\text { period, in } \\
\text { minutes }\end{array}$ & $\begin{array}{l}\text { Total rainfall, in } \\
\text { millimeters }\end{array}$ & $\begin{array}{l}\text { Duration of } \\
\text { dry period } \\
\text { preceding the } \\
\text { event, in } \\
\text { hours }\end{array}$ & $\begin{array}{l}\text { Maximum } \\
\text { flow rate, in } \\
\text { liters per } \\
\text { second }\end{array}$ & $\begin{array}{l}\text { Total flow } \\
\text { volume, in } \\
\text { cubic meters }\end{array}$ \\
\hline SIP 1 & $04-11-95$ & 25 & 63 & 10.70 & 99 & 180 & 304 \\
\hline SIP 1 & $04-17-95$ & 35 & 64 & 19.30 & 120 & 442 & 499 \\
\hline SIP 1 & $09-15-95$ & 45 & 105 & 14.20 & 76 & 303 & 433 \\
\hline SIP 2 & $02-07-95$ & 20 & 75 & 4.10 & 313 & 24.6 & 62 \\
\hline SIP 2 & $04-17-95$ & 35 & 60 & 19.30 & 120 & 210 & 319 \\
\hline PWIP 1 & $09-19-95$ & 10 & 52 & 11.20 & 98 & 2,330 & 2,030 \\
\hline PWIP 1 & $10-10-95$ & 25 & 80 & 9.10 & 102 & 840 & 966 \\
\hline PWIP 2 & $06-27-95$ & 100 & 107 & 10.20 & 340 & 27.0 & 51 \\
\hline PWIP 2 & $08-23-95$ & 20 & 65 & 12.70 & 110 & 61.0 & 94 \\
\hline MIP 1 & $07-14-95$ & 30 & 118 & 4.30 & 192 & 459 & 845 \\
\hline MIP 1 & $07-20-95$ & 70 & 133 & 4.80 & 168 & 279 & 1,160 \\
\hline MIP 2 & $07-20-95$ & 70 & 116 & 4.80 & 168 & 7.39 & 22 \\
\hline MIP 2 & $08-24-95$ & 15 & 86 & 2.54 & 143 & 41.3 & 57 \\
\hline CNIP & $12-11-95$ & 10 & 133 & 2.54 & 284 & 27.0 & 107 \\
\hline CNIP & $01-18-96$ & 10 & 127 & 3.81 & 76 & 172 & 339 \\
\hline SAIP & $01-09-96$ & 40 & 125 & 37.60 & 77 & 750 & 1,320 \\
\hline SAIP & $02-08-96$ & 105 & 125 & 18.54 & 260 & 303 & 500 \\
\hline ZGIP 1 & $03-14-96$ & 120 & 125 & 55.37 & 480 & 765 & 3,280 \\
\hline ZGIP 1 & $03-26-96$ & 5 & 67 & 3.30 & 262 & 22.9 & 28 \\
\hline ZGIP 2 & $03-14-96$ & 120 & 167 & 55.37 & 480 & 164 & 328 \\
\hline ZGIP 2 & $04-23-96$ & 10 & 100 & 5.10 & 140 & 9.63 & 44 \\
\hline
\end{tabular}




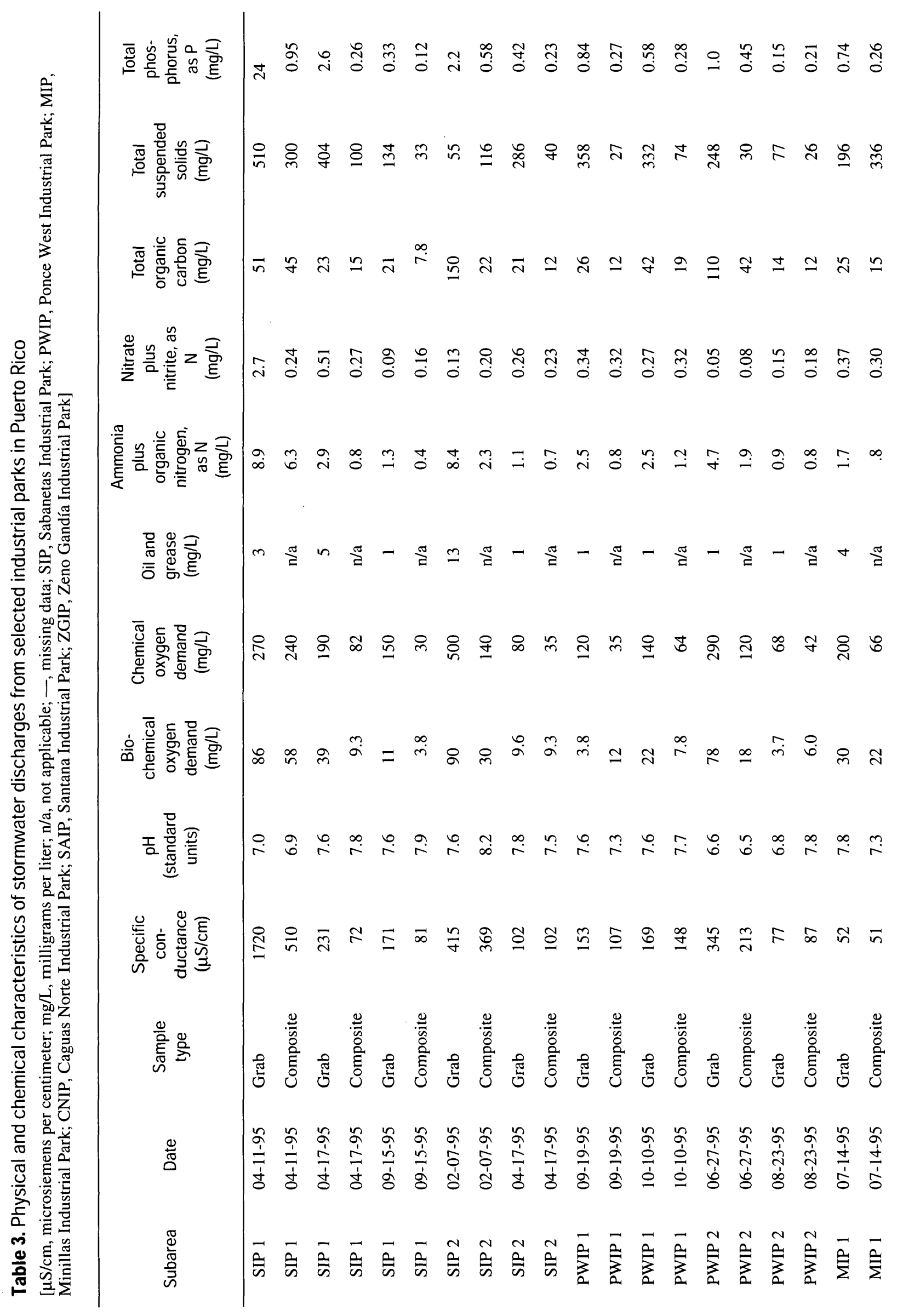




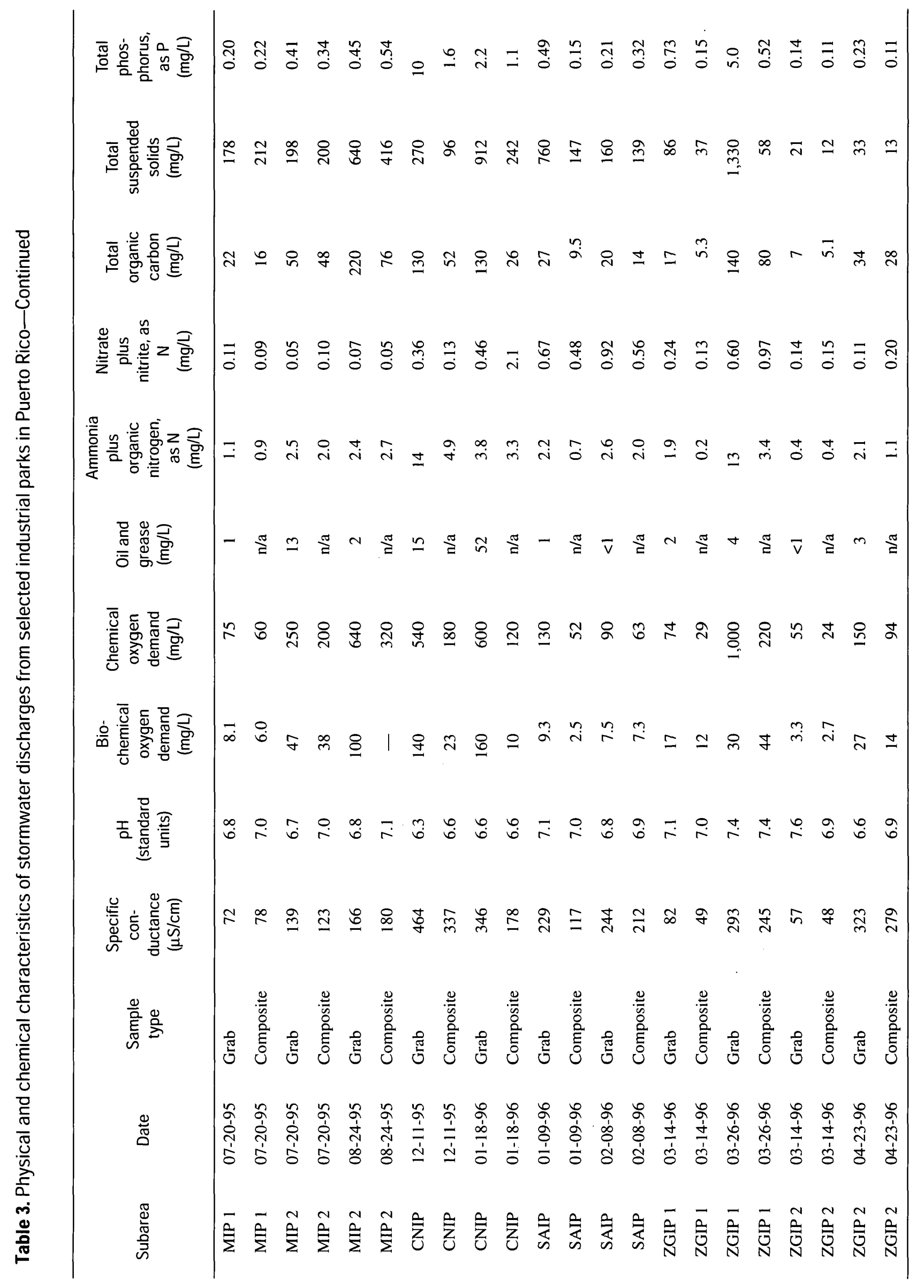




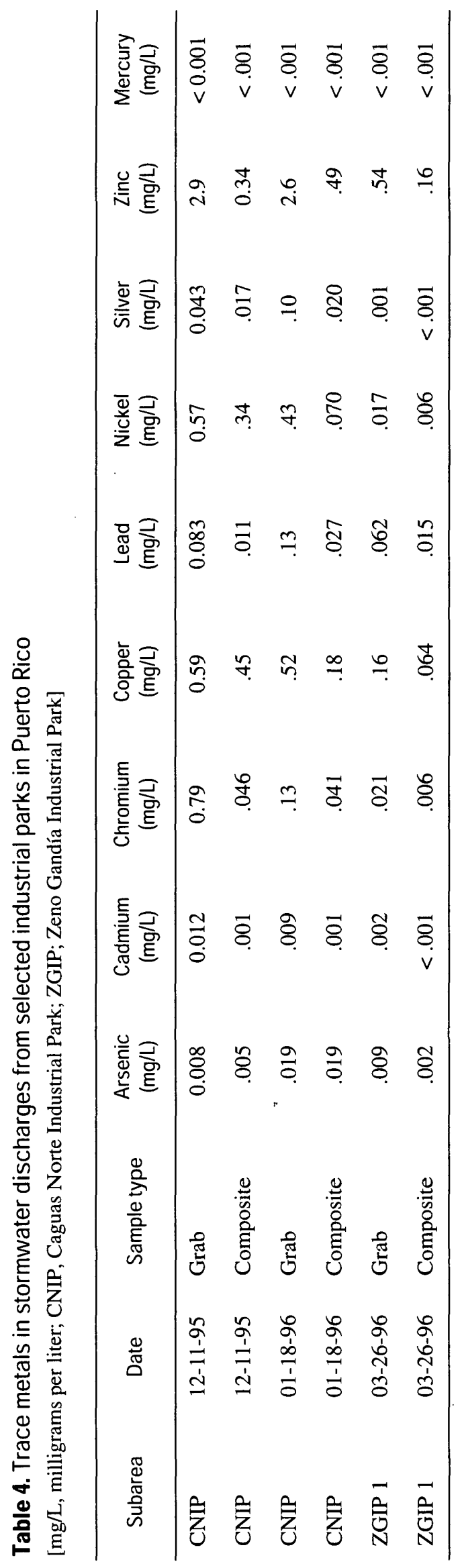



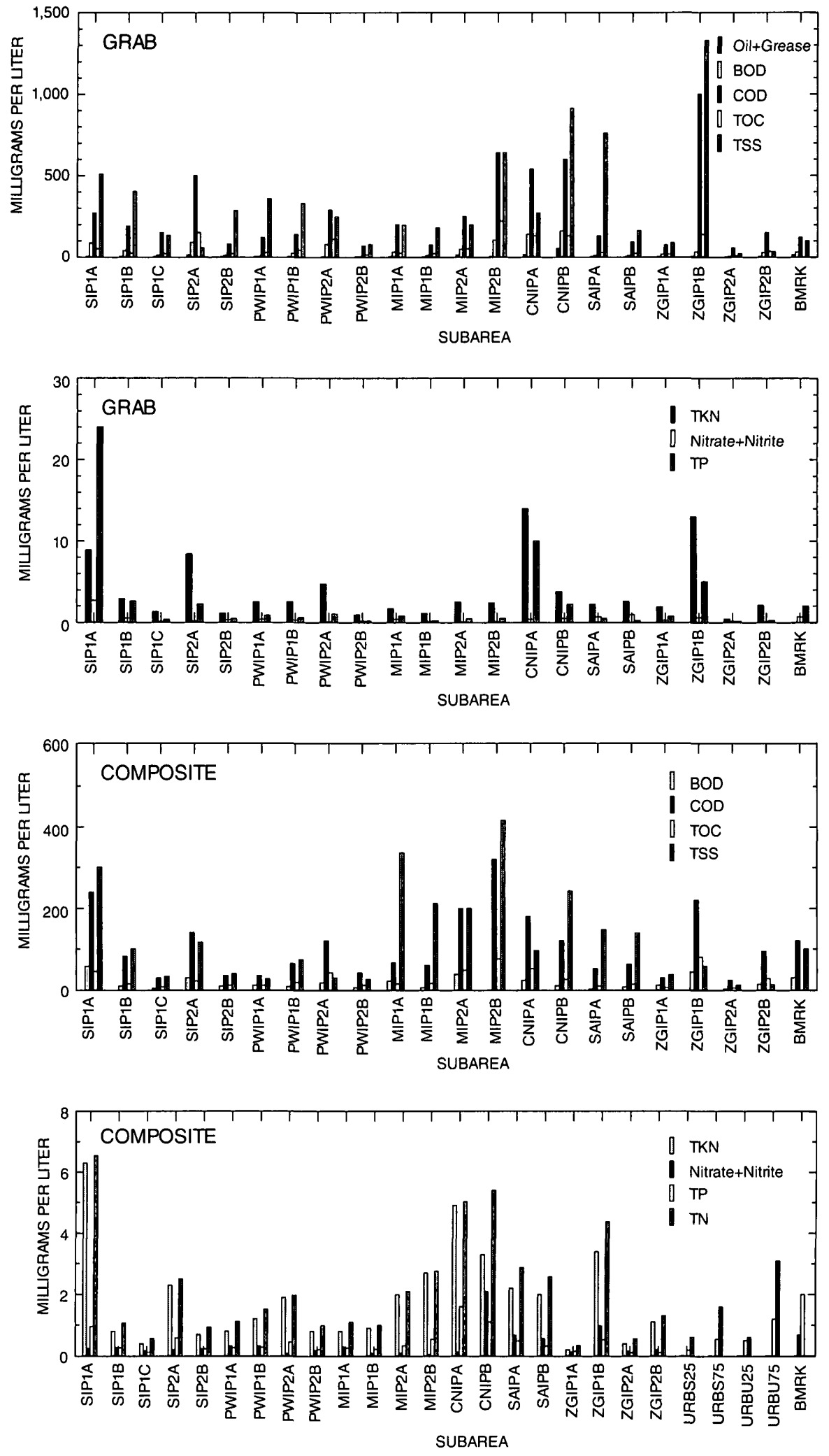

Figure 18. Constituent concentrations in stormwater discharges from industrial parks and urban subareas in Puerto Rico. The letters A, B, and C after the subarea identification represent the first, second, and third sample collected, respectively. 
Table 5. Stormwater benchmark concentrations determined by the U.S. Environmental Protection Agency (1995)

[mg/L, milligram per liter]

\begin{tabular}{lc}
\hline \multicolumn{1}{c}{ Constituent or property } & Benchmark concentration \\
\hline pH (standard unit) & $6.0-9.0$ \\
Biochemical oxygen demand (BOD) $(\mathrm{mg} / \mathrm{L})$ & 30 \\
Chemical oxygen demand (COD) $(\mathrm{mg} / \mathrm{L})$ & 120 \\
Oil and grease (mg/L) & 0.68 \\
Nitrate plus nitrite, as N (mg/L) & 100 \\
Suspended solids, total (TSS) $(\mathrm{mg} / \mathrm{L})$ & 2.0 \\
Phosphorus, total (mg/L) & \\
& 0.16854 \\
Arsenic (mg/L) & 0.0159 \\
Cadmium (mg/L) & 0.0636 \\
Copper (mg/L) & 0.0816 \\
Lead (mg/L) & 1.417 \\
Nickel (mg/L) & 0.0318 \\
Silver (mg/L) & 0.117 \\
Zinc (mg/L) & \\
\hline
\end{tabular}




\section{Constituent Concentrations at Individual Sites}

The average concentration for each analyzed constituent or property (except ammonia plus organic nitrogen and total organic carbon) from the samples collected at each park were compared to benchmark concentrations. For industries under a stormwater permit these values are a target to achieve by the implementation of pollution prevention measures. The comparison of the average concentrations with the benchmark values is an indicator of meeting stormwater quality targets if the industries were under permit. A summary of the benchmark concentrations exceeded at each subarea is presented in table 6 .

\section{SIP 1}

Three events were studied at the SIP 1. During one of these events (March 11, 1995) the by-pass connection from the sanitary sewer pump station located within SIP 1 was in operation. Even though the results of the analyses from the samples collected during this storm event are presented in table 3, they were not used in the calculation of the average concentrations; however, this wastewater-mixed sample is useful in the comparison with samples from subareas where industrial discharges may be present. The average concentrations of COD (170 $\mathrm{mg} / \mathrm{L})$, and TSS $(269 \mathrm{mg} / \mathrm{L})$ in the grab samples exceeded benchmark concentrations in SIP 1.

\section{SIP 2}

Average concentrations of BOD (50 mg/L), COD $(290 \mathrm{mg} / \mathrm{L})$, and TSS (170 mg/L) in the grab samples exceeded benchmark concentrations. The samples collected from the event of February 7, 1995, had extremely high concentrations of constituents which are indicators of pollution by organic material in the discharge. The concentrations of BOD, COD, and TOC during this event are greater than the concentrations of the wastewater-mixed sample collected at SIP 1.

Table 6. Summary of subareas where constituent concentrations exceeded benchmark values

[SIP, Sabanetas Industrial Park; PWIP, Ponce West Industrial Park; MIP, Minillas Industrial Park; CNIP, Caguas Norte Industrial Park; SAIP, Santana Industrial Park; ZGIP, Zeno Gandía Industrial Park; BOD, biochemical oxygen demand; COD, chemical oxygen demand; TSS, total suspended solids; TP, total phosphorus; AG, average grab samples; AC, average composite samples; --, not exceeded; na, not applicable]

\begin{tabular}{|c|c|c|c|c|c|c|c|c|c|c|c|c|c|c|}
\hline \multirow[b]{2}{*}{ Subarea } & \multicolumn{14}{|c|}{ Benchmark } \\
\hline & $\mathrm{pH}$ & BOD & COD & $\begin{array}{c}\text { Oil } \\
\text { and } \\
\text { grease }\end{array}$ & $\begin{array}{l}\text { Nitrate } \\
\text { plus } \\
\text { nitrite }\end{array}$ & TSS & $\mathrm{TP}$ & Arsenic & Cadmium & Copper & Lead & Nickel & Silver & Zinc \\
\hline SIPI & -- & -. & $A G$ & -- & -- & $A G$ & -- & na & na & na & na & na & na & na \\
\hline SIP 2 & - & $\mathrm{AG}$ & $\mathrm{AG}$ & -- & -- & AG & -- & na & na & na & na & na & na & na \\
\hline PWIP 2 & -- & $A G$ & AG & -- & -- & AG & - & na & na & na & na & na & na & na \\
\hline MIP 1 & -- & -- & $\mathrm{AG}$ & -- &.- & $\begin{array}{l}\mathrm{AG} \\
\mathrm{AC}\end{array}$ & -- & na & na & na & na & na & na & na \\
\hline MIP 2 & -- & $\mathrm{AG}$ & $\begin{array}{l}\mathrm{AG} \\
\mathrm{AC}\end{array}$ & -- & -- & $\begin{array}{l}\mathrm{AG} \\
\mathrm{AC}\end{array}$ & -- & na & na & na & na & na & na & na \\
\hline ZGIP 1 & -- & -- & $\begin{array}{l}\mathrm{AG} \\
\mathrm{AC}\end{array}$ & -- & - & $\mathrm{AG}$ & AG & -- & -- & -- & -- & -- & -- & -- \\
\hline ZGIP 2 & -- & -- & -- & -- & -- & -- & -. & na & na & na & na & na & na & na \\
\hline
\end{tabular}




\section{PWIP 1}

Average concentrations of COD (130 mg/L) and TSS (345 mg/L) in the grab samples exceeded the benchmark concentrations.

\section{PWIP 2}

Average concentrations of BOD $(41 \mathrm{mg} / \mathrm{L})$, COD (180 mg/L), and TSS (162 mg/L) in the grab samples exceeded the benchmark concentrations. The samples collected during the event of June 27, 1995, had high concentrations of the constituents (BOD, $\mathrm{COD}, \mathrm{TKN}$, and TOC) that are indicators of pollution from organic material.

\section{MIP 1}

The average concentration of COD $(140 \mathrm{mg} / \mathrm{L})$ in the grab samples exceeded the benchmark concentration. The TSS average concentration in the grab $(187 \mathrm{mg} / \mathrm{L})$ and the composite sample (274 $\mathrm{mg} / \mathrm{L}$ ) also exceeded the benchmark values. The high value of TSS in the composite sample indicates a source of available sediment during the event. A construction project in the subarea during the study may have contributed to this level of sediments.

\section{MIP 2}

Average concentrations in the grab and composite samples of COD (440 and $260 \mathrm{mg} / \mathrm{L}$ ) and TSS (419 and $308 \mathrm{mg} / \mathrm{L}$ ) exceeded the benchmark concentrations. These high values in the grab and composite may be indicative of not only the accumulation of material prior the event, but a continuous source over the sampling period.

The samples collected during the event of August 24, 1995, contained concentrations of organic material indicators in levels resembling those of industrial wastewater rather than stormwater runoff. Compared to the values of the wastewater-mixed samples collected at SIP 1, concentrations of COD and TOC are more than two and four times larger, respectively.

\section{CNIP}

Average concentrations of BOD (150 mg/L), oil and grease $(34 \mathrm{mg} / \mathrm{L})$, and total phosphorus $(6.1 \mathrm{mg} / \mathrm{L})$ in the grab samples exceeded benchmark concentrations. Oil and grease and total phosphorous benchmark concentrations were exceeded only at the CNIP. Average concentrations in the grab and composite sample for COD (570 and $150 \mathrm{mg} / \mathrm{L}$ ) and TSS (591 and $169 \mathrm{mg} / \mathrm{L}$ ) exceeded the benchmark concentrations. Average concentration of nitrate plus nitrite as $\mathrm{N}(1.1 \mathrm{mg} / \mathrm{L})$ in the composite samples exceeded benchmark levels. The highest concentration of ammonia plus organic nitrogen $(14 \mathrm{mg} / \mathrm{L})$ of all the subareas was detected at the CNIP.

Samples from the CNIP were analyzed also for metals (table 5). Benchmark values were exceeded by average concentrations (grab and composite) of copper ( 0.56 and $0.32 \mathrm{mg} / \mathrm{L})$ and zinc (2.8 and 0.42 $\mathrm{mg} / \mathrm{L})$. The average concentration of lead $(0.11 \mathrm{mg} / \mathrm{L})$ and silver $(.072 \mathrm{mg} / \mathrm{L})$ in the grab sample also exceeded the benchmark values. The high concentrations of all the analyzed constituents in both sampled events indicative of the presence of industrial wastes in the storm sewer of the park.

\section{SAIP}

As discussed previously, the SAIP was included in the study to collect data from an area not industrially developed. The collected data could be compared to the data collected in fully developed parks.

All average concentrations, except nitrate plus nitrite as $\mathrm{N}$ in the grab sample $(0.79 \mathrm{mg} / \mathrm{L})$ and TSS in the grab and composite sample (460 and $143 \mathrm{mg} / \mathrm{L}$ ), were below benchmark values. A possible explanation to the levels of nitrate plus nitrite in a nondeveloped park is that the characteristics of the stormwater in the SAIP are influenced by ground water. As discussed in the Site Drainage section, apparently ground water infiltrates to the storm sewer system due to the proximity of the water table to the land surface in the area. A review of the ground water nitrate plus nitrite concentrations in wells located near the SAIP showed 
that concentrations ranged from 0.83 to $2.9 \mathrm{mg} / \mathrm{L}$ (Roman-Mas and Ramos-Ginés, 1988).

The high concentrations of TSS at the SAIP may be caused by the high rain intensity of the two studied events at the SAIP, the low percentage (9 percent) of impervious surface, and a construction project in the area during the study. Large concentrations of suspended material are generally associated to greater rainfall intensity and pervious areas (Driver and Tasker, 1990).

\section{ZGIP 1}

Average concentrations of COD $(540 \mathrm{mg} / \mathrm{L})$, TSS $(708 \mathrm{mg} / \mathrm{L})$, and total phosphorus $(2.9 \mathrm{mg} / \mathrm{L})$ in the grab samples exceeded the benchmark values. The highest COD (1,000 mg/L) and TSS (1,330 mg/L) concentrations for all the studied subareas were detected at ZGIP 1. Analyses for metals were conducted to the samples collected during one event at ZGIP 1. Results of these analyses detected concentration for copper $(0.16 \mu \mathrm{g} / \mathrm{L})$ and zinc $(0.54$ $\mu \mathrm{g} / \mathrm{L}$ ) above benchmark values.

The high concentrations of COD, TOC, and TKN in the samples collected on March 26, 1996, indicate the presence of non-stormwater discharges to the storm sewer. The difference between the BOD ( 30 $\mathrm{mg} / \mathrm{L})$ and $\operatorname{COD}(1,000 \mathrm{mg} / \mathrm{L})$ concentrations may indicate the presence of compounds resistant to biochemical oxidation, possibly produced by an industrial discharge.

\section{ZGIP 2}

Average concentrations for all the analyzed constituents and properties were below benchmark values at the ZGIP 2.

\section{Mass and Mass Per Area Calculations}

Values of mass and mass per area calculated for each constituent are presented in tables 7 and 8 . To calculate the mass of each constituent present in a grab sample, each concentration was multiplied by the flow volume at the time of the grab sample collection (U.S. Environmental Protection Agency, 1991). The mass of the selected constituents detected in the composite sample was calculated by multiplying each constituent concentration by the total volume of discharge during the sampling period. Concentrations of values below the detection level (less than values) were assumed to be zero; therefore, mass and mass per area values were not calculated for those concentrations.

The mass values calculated for the grab samples for oil and grease ranged from 0 to $530 \mathrm{~g}$; BOD, 50.3 to $2,460 \mathrm{~g}$; COD, 420 to $20,400 \mathrm{~g}$; TOC, 85.0 to 4,420 $\mathrm{g}$; and TSS, 92.5 to $76,200 \mathrm{~g}$. Mass values calculated for grab samples for TKN ranged from 4.25 to $425 \mathrm{~g}$; nitrate plus nitrite as $\mathrm{N}, 0.085$ to $67.2 \mathrm{~g}$; and $\mathrm{TP}, 0.645$ to $143 \mathrm{~g}$.

The mass values calculated for the composite samples for BOD ranged from 564 to $39,400 \mathrm{~g}$; COD, 3,950 to $95,300 \mathrm{~g}$; TOC, 1,060 to $24,300 \mathrm{~g}$; and TSS, 573 to $284,000 \mathrm{~g}$. Mass values for TKN ranged from 44 to $1,620 \mathrm{~g}$; nitrate plus nitrite, 2.20 to $712 \mathrm{~g}$; TP, 4.85 to $547 \mathrm{~g}$.

The mass per area values calculated for grab samples for oil and grease ranged from 0 to 4.26 $\mathrm{mg} / \mathrm{m}^{2}$; BOD, 0.37 to $17.2 \mathrm{mg} / \mathrm{m}^{2}$; COD, 3.79 to 158 $\mathrm{mg} / \mathrm{m}^{2}$; TOC, 0.759 to $34.2 \mathrm{mg} / \mathrm{m}^{2}$; and TSS, 1.20 to $921 \mathrm{mg} / \mathrm{m}^{2}$ (table 7). Mass per area computed for TKN ranged from 0.038 to $3.29 \mathrm{mg} / \mathrm{m}^{2}$; nitrate plus nitrite as $\mathrm{N}, 0.001$ to $0.812 \mathrm{mg} / \mathrm{m}^{2}$; and TP, 0.006 to $1.11 \mathrm{mg} / \mathrm{m}^{2}$.

The mass per area values computed for the composite samples for BOD ranged from 5.85 to 188 $\mathrm{mg} / \mathrm{m}^{2}$; COD, 29.3 to $829 \mathrm{mg} / \mathrm{m}^{2}$; TOC, 9.43 to 188 $\mathrm{mg} / \mathrm{m}^{2}$; TSS, 7.41 to $2,340 \mathrm{mg} / \mathrm{m}^{2}$. Values for TKN ranged from 0.390 to $12.6 \mathrm{mg} / \mathrm{m}^{2}$; nitrate plus nitrite, .020 to $7.65 \mathrm{mg} / \mathrm{m}^{2}$; TP, 0.063 to $4.24 \mathrm{mg} / \mathrm{m}^{2}$.

\section{Relation of Storm Characteristics to Stormwater Quality}

Three characteristics of the storm events measured during this study, rain intensity, total runoff volume, and dry period preceding the event were compared to the constituent concentrations produced at each subarea. Even though only two samples were collected at each subarea, this comparison gives an insight into the relation of the constituents with these storm characteristics. 


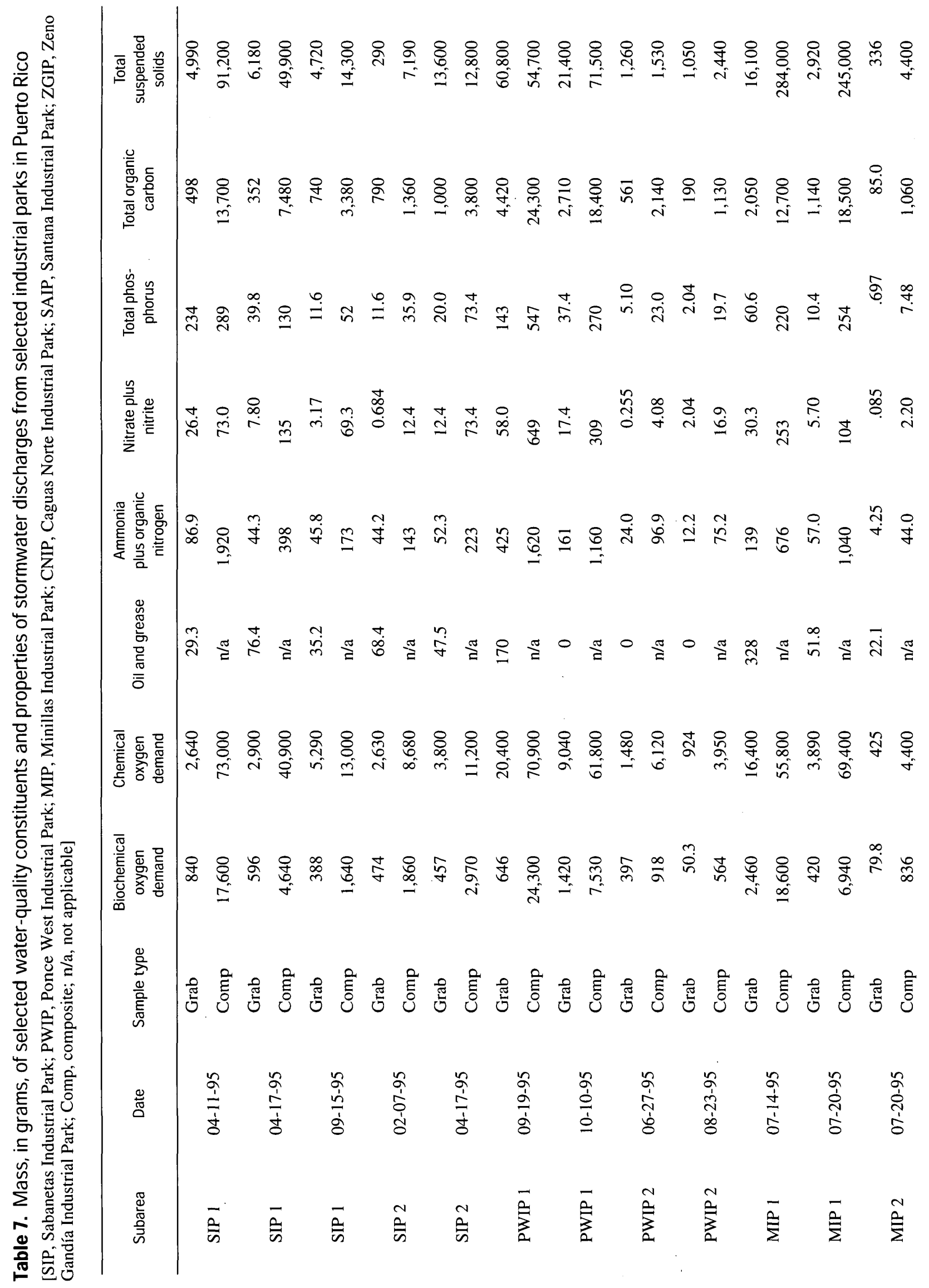




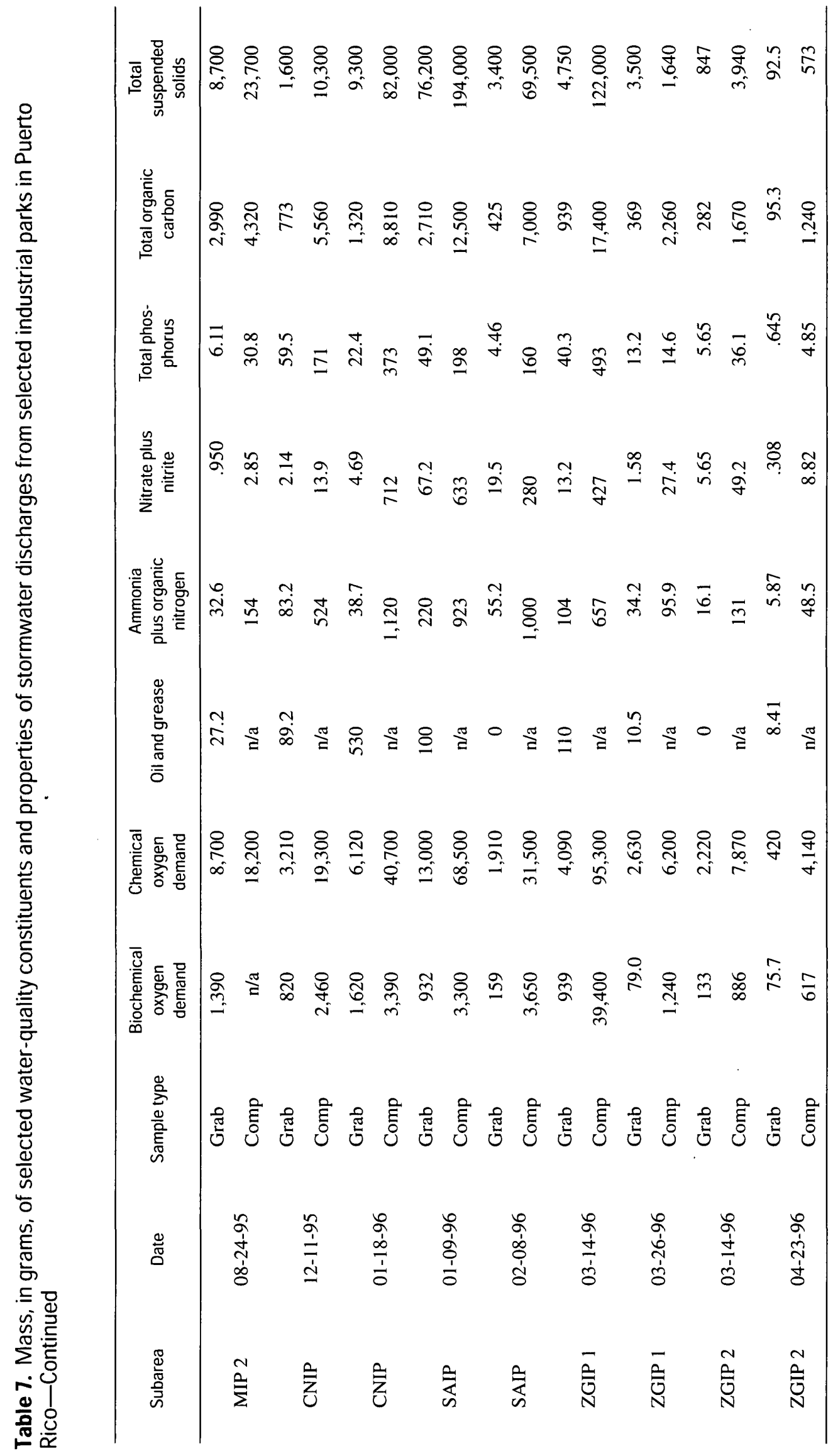




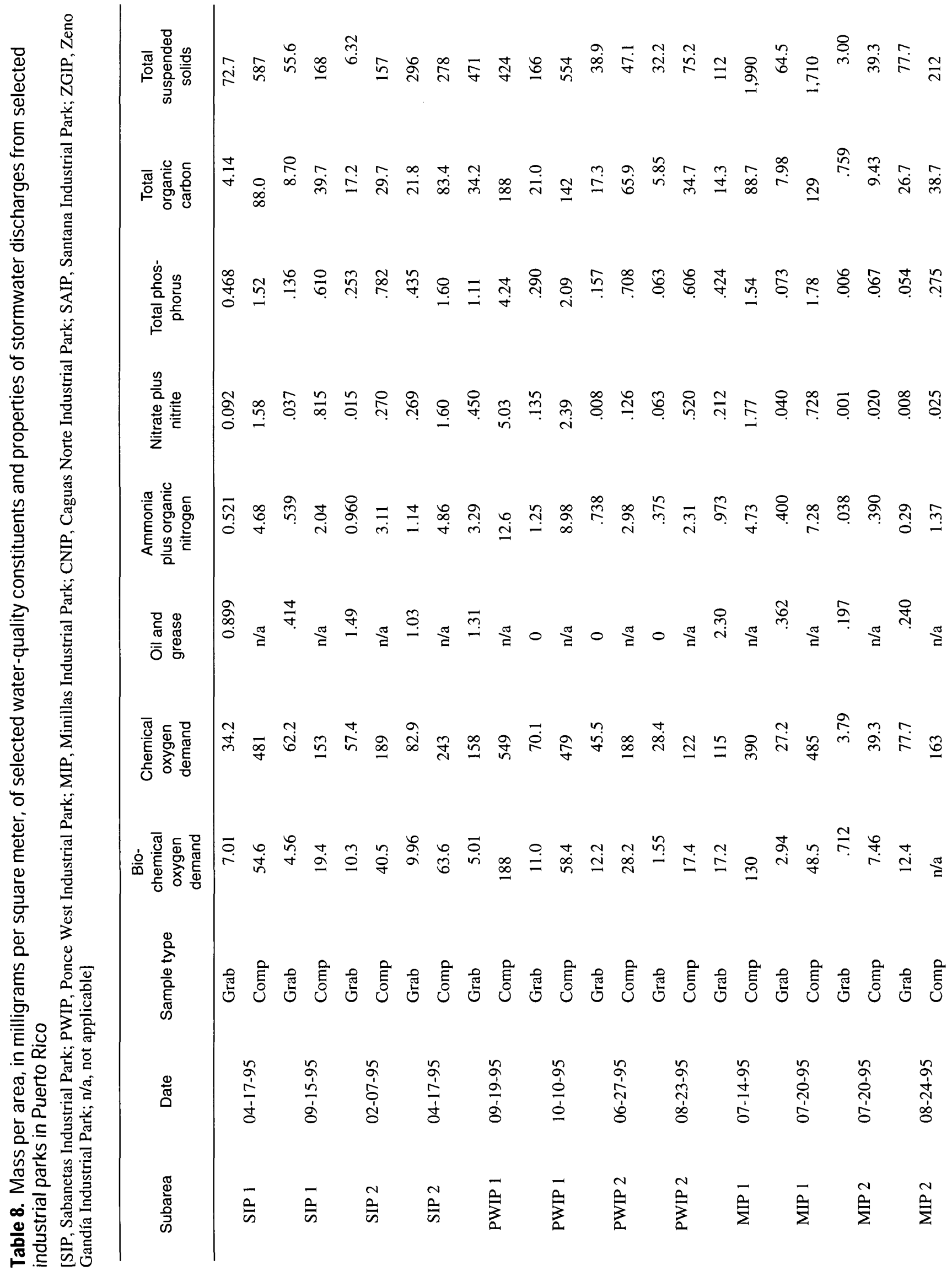




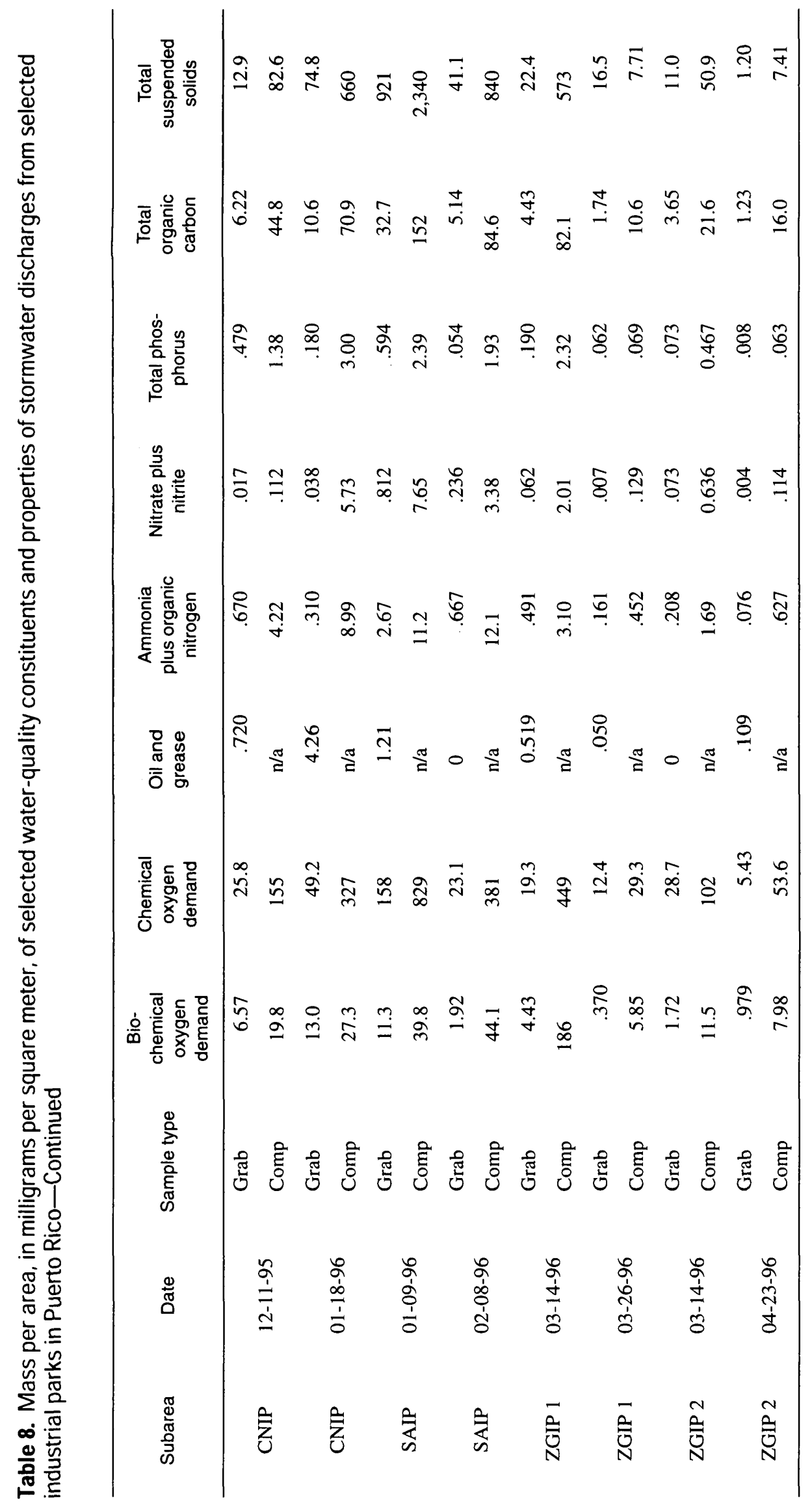


The comparison between the concentration of the analyzed constituents in grab samples and the rain intensity of the events at each subarea showed that the relation varied depending on the constituent.

Concentrations of BOD, COD, TKN, and TP showed an inverse relation to rain intensity in more than half of the studied subareas (fig. 19). This inverse relation may be caused by the dilution effect of a higher intensity rainfall. TSS concentrations increased with rain intensity in 6 of 10 subareas. Generally higher intensity rainfalls are associated to larger concentrations of suspended material (Driver and Tasker, 1990).
The concentration for each constituent of the composite sample was compared to the total volume of runoff produced during the storm events (fig. 20). Concentrations of BOD, COD, TOC, and TKN showed a tendency to decrease with higher volume of runoff. No significant change was observed for nitrate plus nitrate, TSS, and TP.

The other meteorological characteristic compared to the concentration was the dry period preceding the storm (fig. 21). Positive relation between concentrations of most of the constituents in the grab samples with dry periods were observed in SIP 1, SIP 2, PWIP 2, and MIP 1. TKN showed positive relation to the dry period in six of the studied subareas.
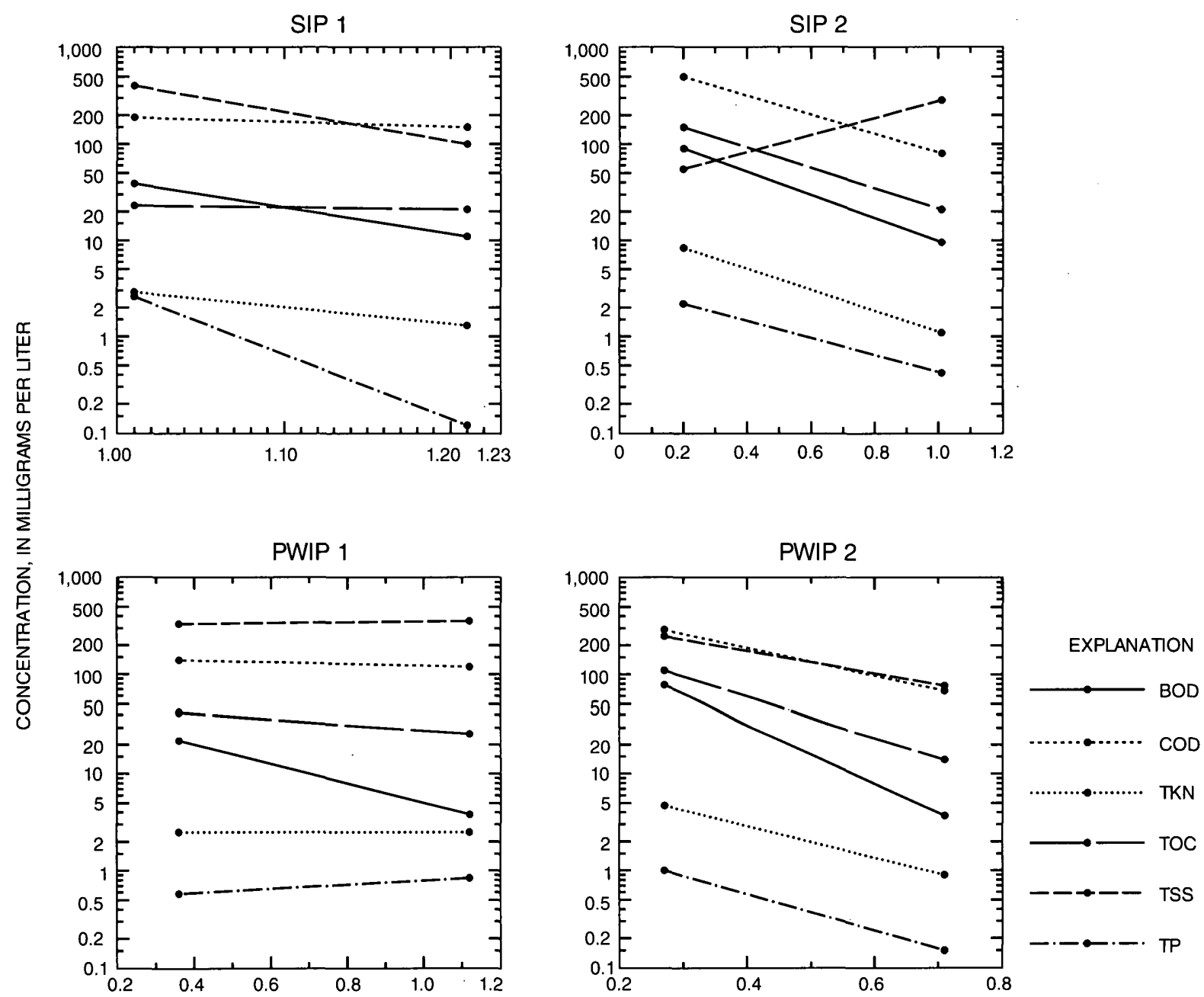

RAIN INTENSITY, IN MILIMETERS PER MINUTE

Figure 19. Relation of constituent concentration in grab samples with the rain intensity of the storm events. 
MIP 1

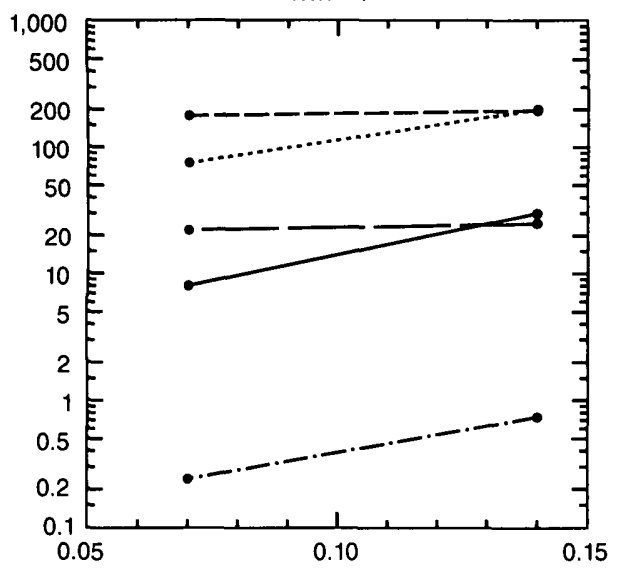

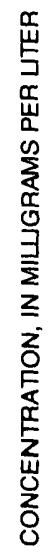
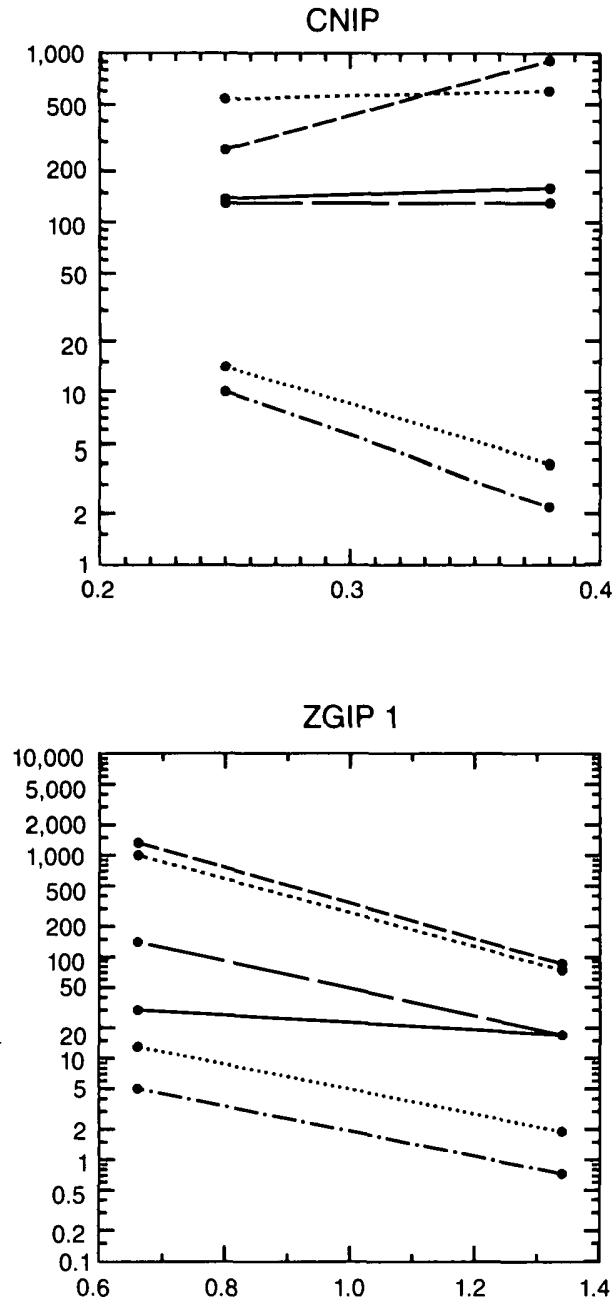

MIP 2
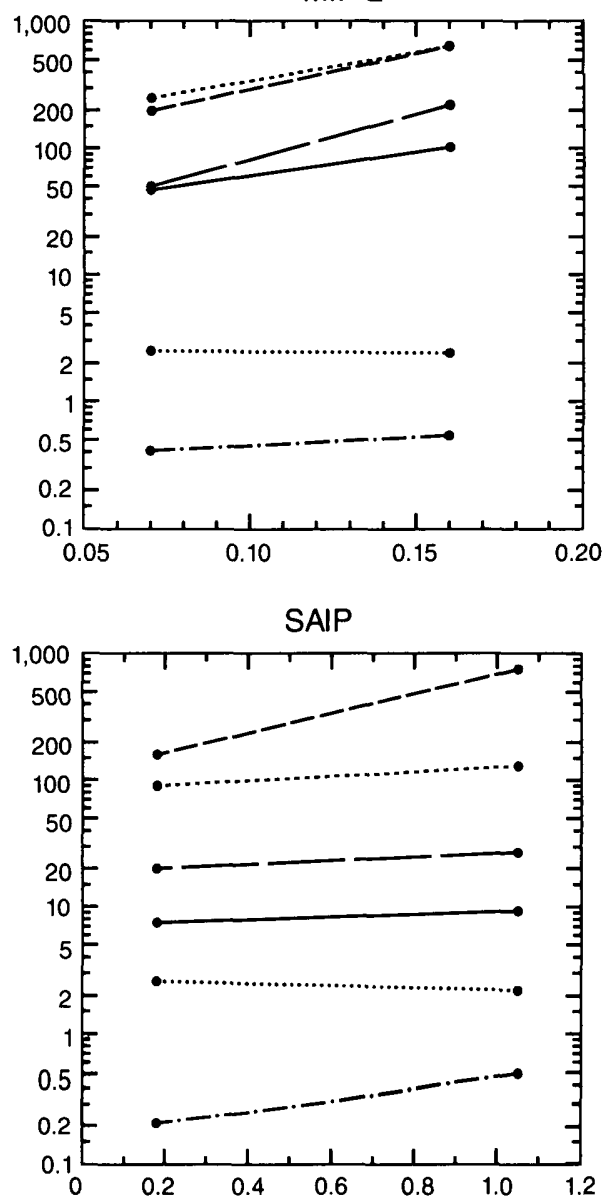

ZGIP 2

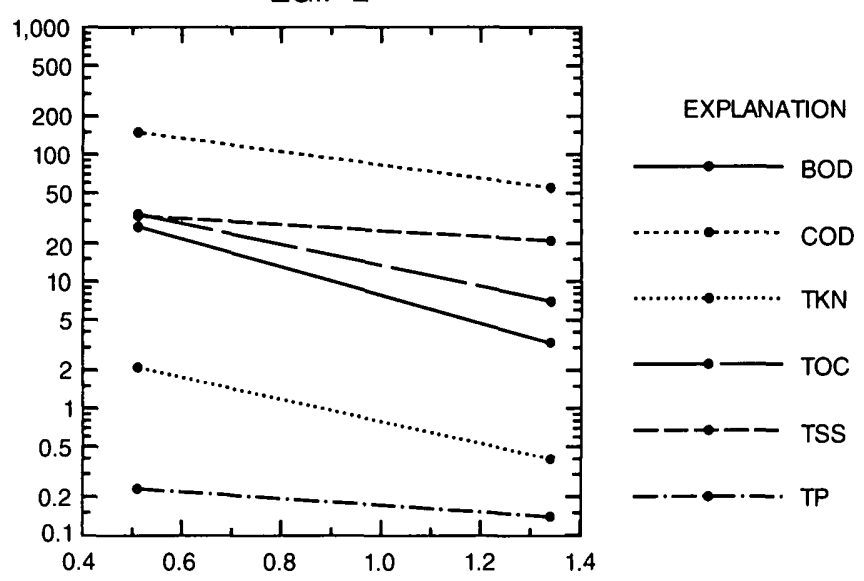

RAIN INTENSITY, IN MILLIMETERS PER MINUTE

Figure 19. Relation of constituent concentration in grab samples with the rain intensity of the storm events-Continued. 

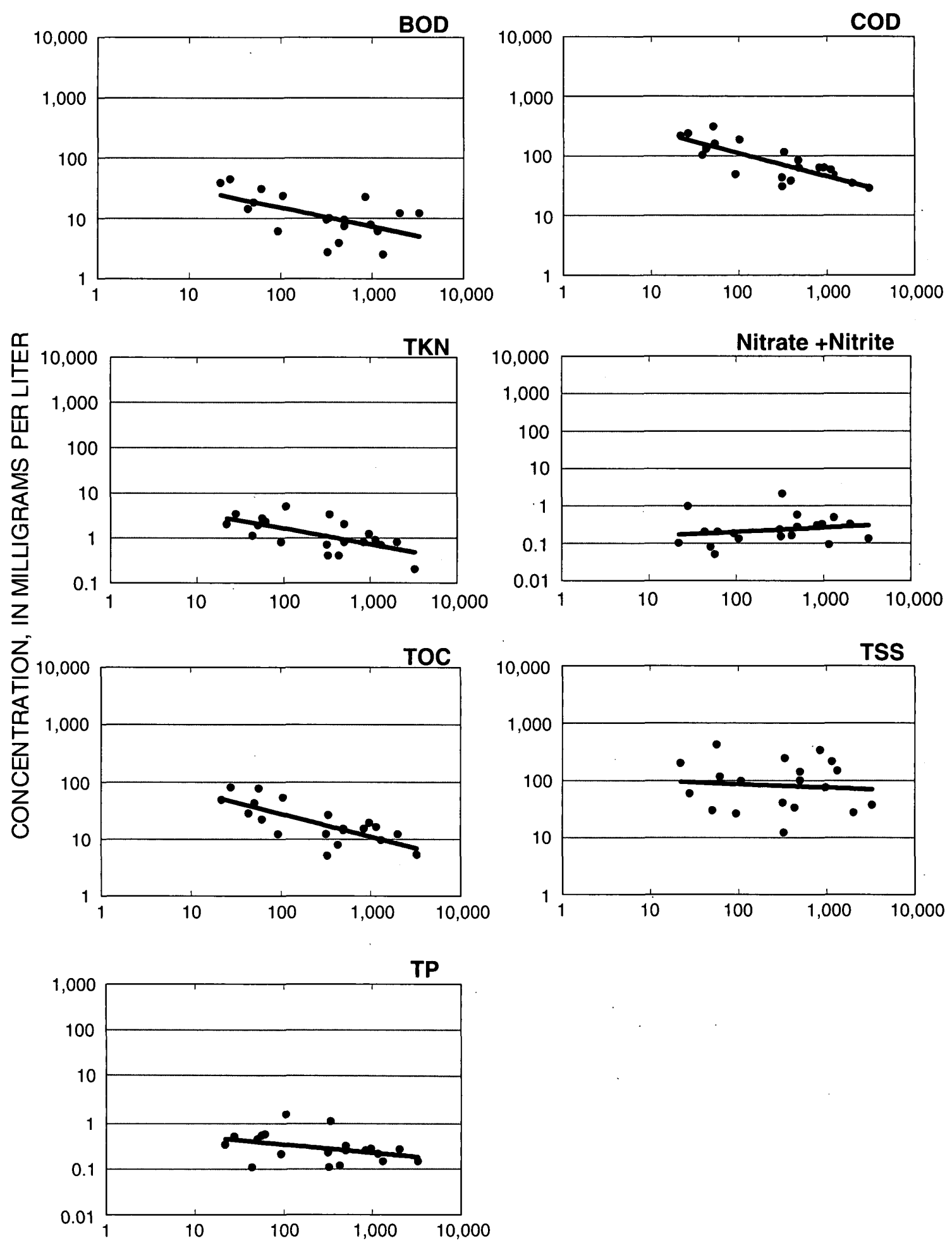

VOLUME OF RUNOFF, IN CUBIC METERS

Figure 20. Relation of constituent concentration in composite samples to volume of runoff at each studied industrial subarea. 

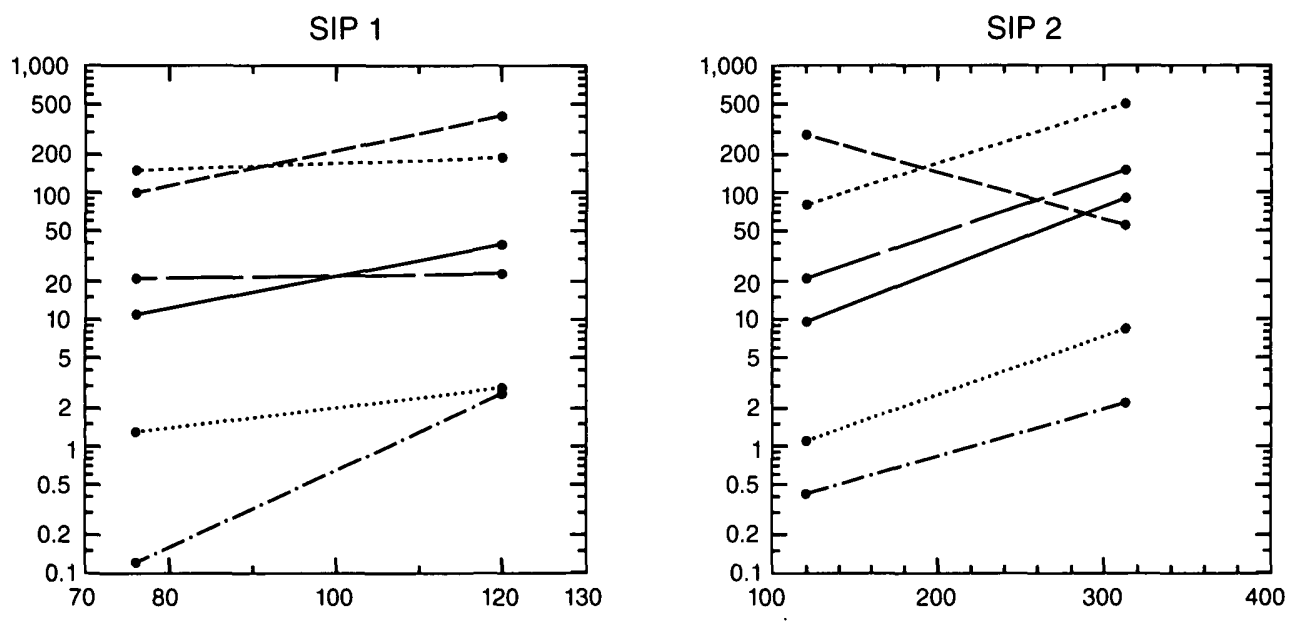

PWIP 1

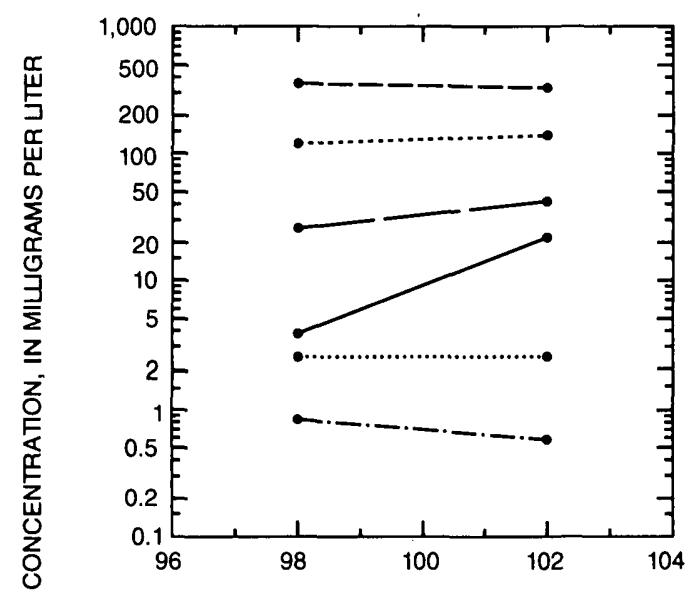

PWIP 2
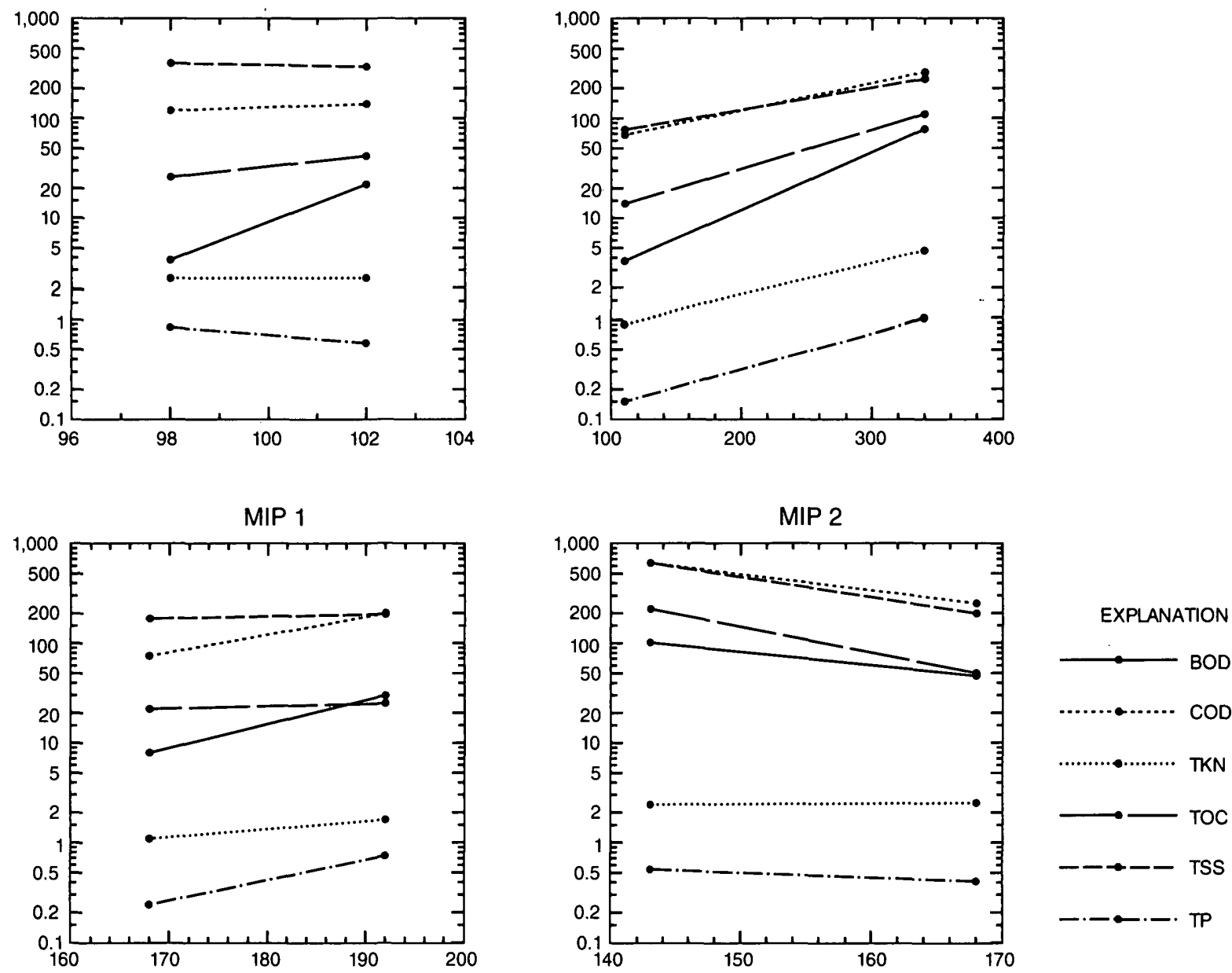

PRECEDING DRY PERIOD, IN HOURS

Figure 21. Relation of constituent concentration in grab samples with the dry period preceding the sampled event. 

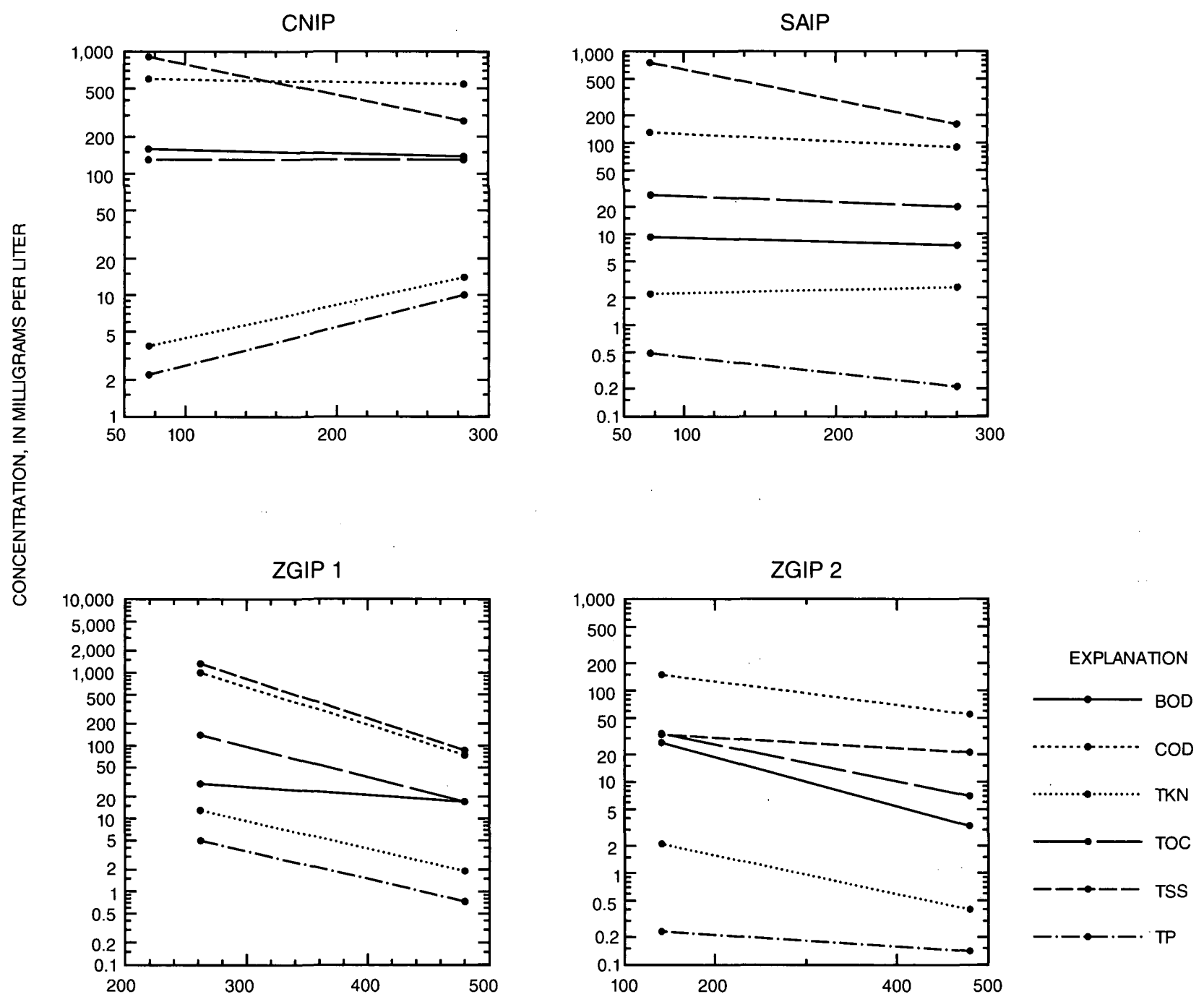

PRECEDING DRY PERIOD, IN HOURS

Figure 21. Relation of constituent concentration in grab samples with the dry period preceding the sampled event-Continued. 


\section{RELATION OF INDUSTRIAL ACTIVITIES TO STORMWATER QUALITY}

Selected information was collected related to the type of industrial activity conducted by each building tenant within the studied subareas (table 9). The types of industrial activities were classified using the Standard Industrial Classification (SIC) (U.S. Executive Office of the President, 1987). Depending on the level of detail the SIC can use a 2- to 4-digit grouping system, in which the first two digits shows the major group, the third shows the industry group, and the fourth shows the industry code. In this report the 2-digit classification is used.

Studies conducted which relate the types of industrial activities to the results of the analyses of the stormwater reported by industries in the permitting process showed that certain industrial groups had higher potential to discharge pollutants at concentrations of concern (U.S. Environmental Protection Agency, 1995). Some of the industrial groups which presented higher potential to discharge pollutants are represented at the studied subareas. These industrial groups are classified under SIC 20, 28,33 , and 34 .

Industries from group 20 (food and related products) were established on subareas PWIP 1, MIP 1, MIP 2, CNIP, and ZGIP 1. Some of the potential pollutants from this industrial group are BOD, oil and grease, TKN, and TSS. Average concentrations exceeding the benchmark values for one or more of these parameters were detected at MIP 2 and CNIP. The highest concentration of ammonia plus organic nitrogen and oil and grease for all the studied subareas was detected at CNIP.

Industries from group 28 (chemicals and allied products) were represented on PWIP 1, MIP 1, MIP 2, and CNIP. Two of the pollutants of concern for this group, nitrate plus nitrite and total phosphorus, were analyzed during this study. The benchmark values for these constituents were exceeded at CNIP.
Industrial group 33 (primary metals industries) and 34 (fabricated metals products) are represented in PWIP 1, MIP 1, MIP 2, CNIP and ZGIP 2. Some of the pollutants of concern for these industrial groups are oil and grease, COD, nitrate plus nitrite, TSS, and metals. The COD average concentrations for grab samples exceeded the benchmark values in most of the studied subareas (except SAIP and ZGIP 2); however CNIP and MIP 2 had the highest and third highest average concentration. Oil and grease, nitrate plus nitrite, and TSS concentrations were discussed in relation to other industrial groups. Analyses for metals performed on samples collected at the CNIP showed average concentrations of copper, lead (grab), silver (grab), and zinc exceeded benchmark values.

Potential pollutant sources associated to industrial groups other than those discussed above, may be present at the studied subareas. Pollutants associated to activities conducted by industrial group 35 (industrial and commercial equipment) and 36 (electronic and electrical equipment), which are represented in six subareas, include TSS, metals, oil and grease, and organics. Distinctive concentrations of TOC were found in three (SIP 2, PWIP 2, and ZGIP 1) of the six subareas where activities from industrial group 35 and 36 are conducted. At ZGIP 1 and SIP 2 the average concentration of TKN showed levels only surpassed by levels at CNIP. As discussed in the Quality of Stormwater Discharges section the high concentrations of BOD, COD, TOC, TP, TKN, and metals indicates the presence of industrial discharges to the storm sewer at SIP 2, CNIP, MIP 2, and ZGIP 1. 
Table 9. Industrial activities at selected industrial parks in Puerto Rico [--; no information]

\begin{tabular}{|c|c|c|c|c|}
\hline Subarea & Lot number & $\mathrm{SIC}$ & Major industrial group & Main product \\
\hline SIP 1 & $1-5,14-17$ & 38 & $\begin{array}{l}\text { Measuring, analyzing, and controlling instruments; } \\
\text { medical and optical goods }\end{array}$ & Surgical instruments \\
\hline SIP 1 & 6 & 23 & Apparel and other finished products made from fabrics & Sports uniforms \\
\hline SIP 1 & 6 & 36 & Electronic and other electrical equipment & Electronic tags \\
\hline SIP 1 & 6 & 36 & Electronic and other electrical equipment & Electric panels transformers \\
\hline SIP 1 & 7 & 87 & $\begin{array}{l}\text { Engineering, accounting, research, management, and } \\
\text { related services }\end{array}$ & Testing laboratory \\
\hline SIP 1 & 7 & 39 & Miscellaneous manufacturing & Jewelry \\
\hline SIP 1 & 8 & 30 & Rubber and miscellaneous plastics & Plastic products \\
\hline SIP 1 & 9 & 38 & $\begin{array}{l}\text { Measuring, analyzing, and controlling instruments; } \\
\text { medical and optical goods }\end{array}$ & $\begin{array}{l}\text { Disposable medical } \\
\text { products }\end{array}$ \\
\hline SIP1 & $11-13$ & -- & Vacant & -- \\
\hline SIP 2 & $21,23,31$ & 38 & $\begin{array}{l}\text { Measuring, analyzing, and controlling instruments; } \\
\text { medical and optical goods }\end{array}$ & Plastic lenses \\
\hline SIP 2 & 29,30 & 36 & Electronic and other electrical equipment & Electronic tags \\
\hline PWIP 1 & 20 & 20 & Food and related products & Baked products \\
\hline PWIP 1 & 20 & 30 & Rubber and miscellaneous plastics & Plastic products \\
\hline PWIP 1 & 20 & 37 & Transportation equipment & Aircraft parts \\
\hline PWIP 1 & 20 & 28 & Chemicals and allied products & Adhesives and sealants \\
\hline PWIP 1 & 21 & 42 & Trucking and warehousing & -- \\
\hline PWIP 1 & 22,23 & 35 & Industrial and commercial equipment & $\begin{array}{l}\text { Electrical motors } \\
\text { reconstruction }\end{array}$ \\
\hline PWIP 1 & 24 & 34 & Fabricated metal products & Air conditioning conductors \\
\hline PWIP 1 & 25 & 34 & Fabricated metal products & Air conditioning conductors \\
\hline PWIP 1 & 26 & 20 & Food and related products & Baked products \\
\hline PWIP 1 & 26 & 30 & Rubber and miscellaneous plastics & Plastic bags \\
\hline PWIP 1 & $27-30$ & 35 & Industrial and commercial equipment & Computer backup tapes \\
\hline PWIP 1 & $31-32$ & 37 & Transportation equipment & Automotive parts \\
\hline PWIP 1 & 33 & 23 & Apparel and other textile products & Neckware \\
\hline PWIP 2 & 14 & 36 & Electronic and other electrical equipment & Electric connectors \\
\hline PWIP 2 & 15 & 30 & Rubber and miscellaneous plastics & Plastic products \\
\hline PWIP 2 & 16 & 36 & Electronic and other electrical equipment & Night-lights \\
\hline MIP 1 & 47 & 26 & Paper and allied products & Envelopes \\
\hline MIP 1 & 48 & 20 & Food and related products & Dairy products \\
\hline MIP 1 & 48 & 26 & Paper and allied products & Labels \\
\hline MIP 1 & 48 & 32 & Stone, clay, glass, and concrete products & Ceramic products \\
\hline MIP 1 & $49-51$ & 50 & Wholesale trade - durable goods & Metal pipes \\
\hline MIP 1 & 52 & 27 & Printing, publishing, and allied products & Color separation process \\
\hline MIP 1 & 52 & 34 & Fabricated metal products & Metal shearing and bending \\
\hline MIP 1 & $53-54$ & 35 & Industrial and commercial equipment & Machine shop \\
\hline MIP 1 & $53-54$ & 28 & Chemicals and allied products & Hair products \\
\hline MIP 1 & $56 \mathrm{~A}$ & -- & Not available & -- \\
\hline MIP 1 & 57 & -- & Not available & -- \\
\hline MIP 1 & 58 & 36 & Electronic and other electrical equipment & Electronic parts \\
\hline MIP 1 & $59-60,73$ & 28 & Chemicals and allied products & Pharmaceutical products \\
\hline MIP 1 & $69-70$ & -- & Vacant & -- \\
\hline MIP 1 & $71-72$ & 20 & Food and related products & Baked products \\
\hline MIP 1 & $71-72$ & 20 & Food and related products & Cheese turnovers \\
\hline MIP 1 & $71-72$ & 35 & Industrial and commercial equipment & Electrical connectors \\
\hline
\end{tabular}


Table 9. Industrial activities at selected industrial parks in Puerto Rico-Continued

\begin{tabular}{|c|c|c|c|c|}
\hline Subarea & Lot number & SIC & Major industrial group & Main product \\
\hline MIP I & 76 & 30 & Rubber and miscellaneous plastics products & Acrylic products \\
\hline MIP 1 & 76 & 25 & Furniture and fixtures & Vertical blinds \\
\hline MIP 1 & 76 & 38 & $\begin{array}{l}\text { Measuring, analyzing, and controlling instruments; } \\
\text { medical and optical goods }\end{array}$ & Dental products \\
\hline MIP I & 77 & 34 & Fabricated metal products & Screen fasteners \\
\hline MIP 1 & 89 & 33 & Primary metal industries & Die cast \\
\hline MIP 1 & 93 & -- & Non industrial & -- \\
\hline MIP 2 & 20 & 20 & Food and related products & Baked products \\
\hline MIP 2 & 22 & 34 & Fabricated metal products & Awnings \\
\hline MIP 2 & 23 & 20 & Food and related products & Baked products \\
\hline MIP 2 & $24 \mathrm{~A}$ & 34 & Fabricated metal products & Aluminum products \\
\hline MIP 2 & $24 \mathrm{~A}$ & 25 & Furniture and fixtures & Kitchen cabinets \\
\hline MIP 2 & 24B & 34 & Fabricated metal products & Metal cabinets \\
\hline MIP 2 & 25 & 28 & Chemicals and allied products & Paints \\
\hline MIP 2 & 32 & -- & Non industrial & -- \\
\hline MIP 2 & 33 & 20 & Food and related products & Dairy products \\
\hline MIP 2 & 34 & 30 & Rubber and miscellaneous plastics product & Rubber buckets \\
\hline MIP 2 & $35-36$ & 34 & Fabricated metal products & Metal doors \\
\hline CNIP & 5 & 23 & Apparel and other textile products & Clothing \\
\hline CNIP & 7 & -- & Vacant & -- \\
\hline CNIP & 9 & -- & Vacant & -- \\
\hline CNIP & 10 & 50 & Medical, dental, and hospital supplies & Dental supplies \\
\hline CNIP & 11 & 34 & Fabricated metal products & Electroplated products \\
\hline CNIP & 12 & 20 & Food and related products & Meat sausages \\
\hline CNIP & 13 & -- & Not available & -- \\
\hline CNIP & 14 & -- & Not available & -- \\
\hline CNIP & 15 & 23 & Apparel and other textile products & Uniforms \\
\hline CNIP & 16 & 23 & Apparel and other textile products & -- \\
\hline CNIP & 17 & -- & non industrial & -- \\
\hline CNIP & 18 & 37 & Transportation equipment & Automotive parts \\
\hline CNIP & 19 & 20 & Food and related products & Meat products \\
\hline CNIP & 19 & 28 & Chemicals and allied products & Paints \\
\hline CNIP & 20 & 23 & Apparel and other textile products & Clothing \\
\hline CNIP & 21 & -- & Vacant & -- \\
\hline CNIP & 22 & 33 & Primary metal industries & Stamped metal products \\
\hline CNIP & $23-24$ & 23 & Apparel and other textile products & Clothing \\
\hline ZGIP 1 & $22 \mathrm{~A}$ & 20 & Food and related products & Baked products \\
\hline ZGIP 1 & $22 \mathrm{~A}$ & 23 & Apparel and other textile products & Clothing \\
\hline ZGIP 1 & $\begin{array}{l}31,33,35,37, \\
39-41,43\end{array}$ & 35 & Industrial and commercial equipment & Refrigeration equipment \\
\hline ZGIP 1 & $32-33,36$ & 23 & Apparel and other textile product & Clothing \\
\hline ZGIP 1 & 44 & 35 & Industrial and commercial equipment & Computer boards \\
\hline ZGIP 2 & $\begin{array}{l}6,11,12,17 \\
18\end{array}$ & 22 & Textile mill products & Clothing \\
\hline ZGIP 2 & 7 & 36 & Electronic and other electrical equipment & Electric parts \\
\hline ZGIP 2 & 10 & 33 & Primary metal industries & Plastic and zinc products \\
\hline ZGIP 2 & $21 \mathrm{~A}$ & 25 & Furniture and fixtures & Household furniture \\
\hline ZGIP 2 & 23 & 25 & Furniture and fixtures & Household furniture \\
\hline
\end{tabular}




\section{SUMMARY}

Ten drainage subareas distributed within six industrial parks located throughout Puerto Rico were studied to characterize their stormwater discharges. The stormwater flow pattern in all studied parks is mainly from the individual lots to the streets, where it is conveyed by the storm sewer system of the park. Outfalls from the studied subareas discharge to creeks and wetlands, municipal storm sewers, and open ground.

The data collected during the studied storm events showed that almost half of the studied events lasted for 30 minutes or less. Half of the studied storm events had rainfall volume of less than $10 \mathrm{~mm}$.

Calculated runoff for each event ranged from 0.13 to $15.9 \mathrm{~mm}$.

The analyses of the stormwater grab samples collected from the selected industrial parks indicated that COD and TSS average concentrations at most of the subareas exceeded benchmark values determined by USEPA. Four of the studied subareas (SIP 2, MIP 2, CNIP, and ZGIP 1) presented concentrations of indicators of pollution by organic material in levels which resemble those of industrial wastes rather than stormwater discharges. Non-stormwater discharges were observed at two of the studied industrial parks.

Concentrations of constituents in stormwater compared to the rain intensity showed an inverse relation to $\mathrm{BOD}, \mathrm{COD}, \mathrm{TKN}$, and $\mathrm{TP}$ in more than half of the studied subareas. The concentrations of BOD, COD, TOC, and TKN in the composite samples showed a tendency to decrease with higher volume of runoff.

\section{REFERENCES}

Calvesbert, R.J., 1970, Climate of Puerto Rico and the U.S. Virgin Islands: U.S. Department of Commerce, Climatography of the United States no. $60.52,29$ p.

Driver, N.E., and Tasker, G.D., 1990, Techniques for estimation of storm-runoff loads, volumes and selected constituents concentrations in urban watersheds in the United States: U.S. Geological Survey Water Supply Paper 2363, 43 p.

Ramos-Ginés, Orlando, 1997, Water balance and quantification of total phosphorus and total nitrogen loads entering and leaving the Lago de Cidra, central Puerto Rico: U.S. Geological Survey Water Resources Investigations Report 99-4222, 28 p.

Roman-Mas, Angel, and Ramos-Ginés, Orlando, 1988, Compilation of water-quality data for the north coast limestone aquifers, Puerto Rico, 1951. to 1987: U.S. Geological Survey Open File Report 87-533, 133 p.

U.S. Environmental Protection Agency, 1983, Results of the nationwide urban runoff program: U.S. Environmental Protection Agency Final Report, 4 volumes.

1991, Guidance manual for the preparation of NPDES permit applications for stormwater discharges associated with industrial activity: Office of Wastewater Enforcement and Compliance, EPA-505/8-91-002.

1995, Final NPDES storm water multisector general permits for industrial activities: Federal Register, v. 60, n. 189 , p. 50,826.

U.S. Executive Office of the President, 1987, Standard industrial classification manual: Office of Management and Budget, 703 p. 


\author{
District Chief \\ Caribbean District \\ U.S. Geological Survey \\ Water Resources Division \\ GSA Center, Suite 400-15 \\ 651 Federal Drive \\ Guaynabo, Puerto Rico 00965-5703
}

